\title{
Six Essays by Theodore II Laskaris in Vindobonensis Phil. Gr. 321: Edition, Translation, Analysis*
}

\author{
With 4 figures
}

\begin{abstract}
The paper offers a critical edition and translation of six hitherto unedited and practically unknown essays by Theodore II Laskaris (1254-1258), preserved in Vind. phil. gr. 321 within a dossier devoted exclusively to works of the emperor. On the one hand, the edition is accompanied by a detailed study of this dossier along with a reconstruction of its lost copying exemplar, while, on the other, the paper presents an analysis of the six essays, placing them in the political, intellectual and cultural context of the late Nicaean Empire.
\end{abstract}

Emperor Theodore II Laskaris (1221/22-1258) was a prolific and unconventional author whose literary inclinations and probing mind are yet to be fully understood. His writings include - among other genres and generic variations - letters, oratory, natural philosophy, hymnography, satire, and political theory. It is little known that he also tried his hand at brief essayistic compositions. Six essays by Laskaris have been preserved in a famous manuscript dating to the second half of the thirteenth century, which is part of the collections of the Österreichische Nationalbibliothek, the Vind. phil. gr. 321 (V). The essays have remained unedited until today despite their considerable interest and brief description in Herbert Hunger's catalogue. The goal of the present article is to offer an editio princeps and set the essays within their broader textual, literary, and biographical framework. In contrast to conventional practice, the article starts with the critical edition and an accompanying English translation, because we would like the readers to get an unmediated impression of these very special texts. The study of the manuscript has led us to offer a working hypothesis about its scribe and identify the two authorized editions of Laskaris' works, from which the substantial dossier of his texts in V was extracted. Since Laskaris' editorial project has not yet received due palaeographical and codicological attention, we will proceed to reconstruct for the first time a hitherto unnoticed authorized edition produced late in his life, in which the six essays were originally included. Our interpretative analysis considers the date, audience, and literary features of the essays, and discusses some of their peculiar ideas and characteristics.

\footnotetext{
* The present article is an expanded and fully revised version of a seminar given at the Vienna Institute of Byzantine and Modern Greek Studies in June 2017. We would like to thank Claudia Rapp and Andreas Rhoby for their hospitality, and the participants in the seminar for the lively discussion and the insightful comments. We are particularly indebted to Katharina Kaska at the Österreichische Nationalbibliothek for her assistance with our study of V, Otto Kresten for sharing with us his profound knowledge of the history of the ÖNB's Greek manuscript collection, and Christian Förstel for his assistance with the Paris manuscripts of Laskaris' works. Special thanks go to Börje Bydén, Carolina Cupane, Antonia Giannouli, Martin Hinterberger, Joseph Munitiz, Diether Roderich Reinsch and the two anonymous reviewers for their help, be it in matters of edition, translation or interpretation of the six essays.

The following abbreviations to modern editions of Theodore Laskaris' works have been used: ep. Festa: N. Festa, Theodori Ducae Lascaris epistulae CCXVII. Florence 1898.

TARTAglia, Opuscula: L. TARTAgLia, Theodorus II Ducas Lascaris: Opuscula rhetorica. Munich 2000.

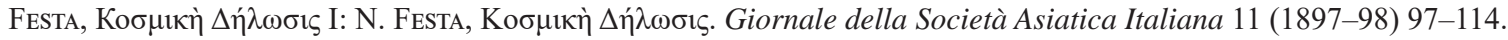

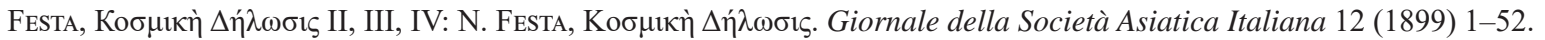

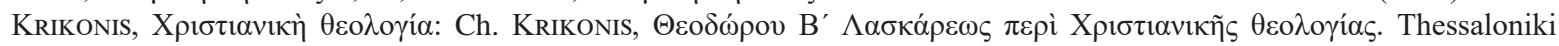
1988.

Angelov, Moral Pieces: D. Angelov, The Moral Pieces by Theodore II Laskaris. DOP 65-66 (2011-12) 237-269.
} 


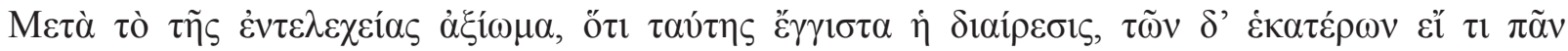

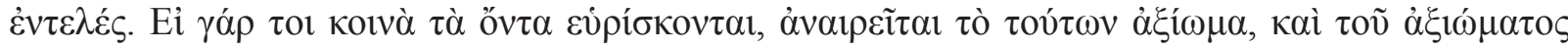

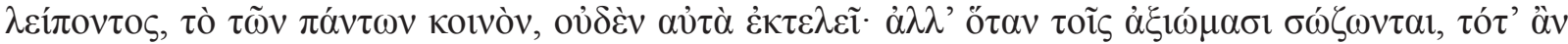

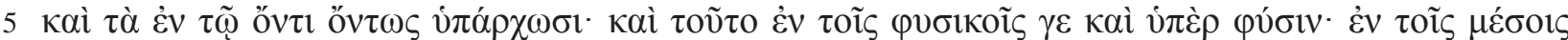

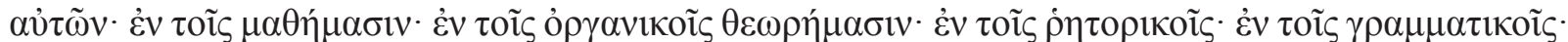

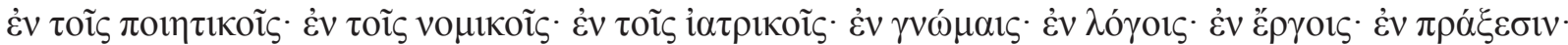

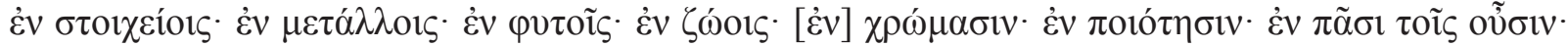

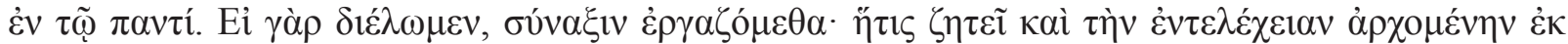

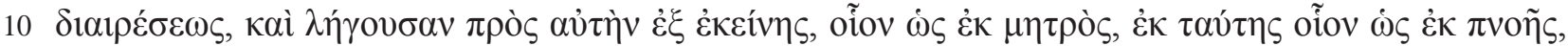

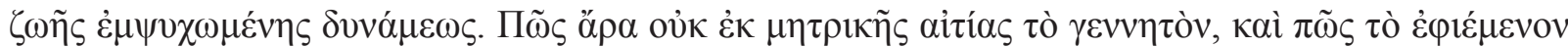

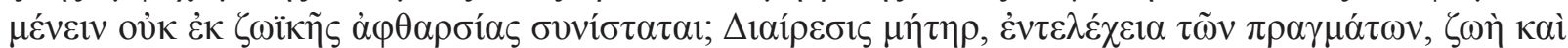

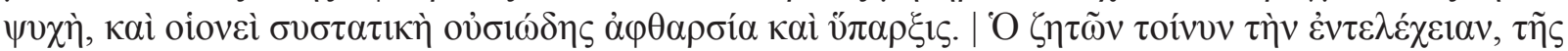

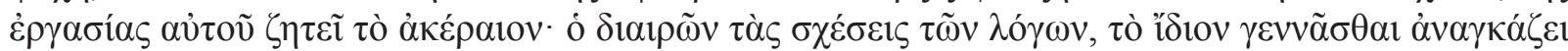

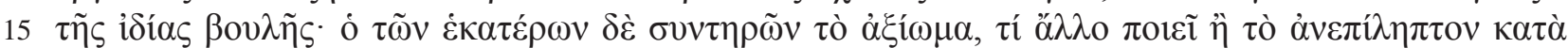

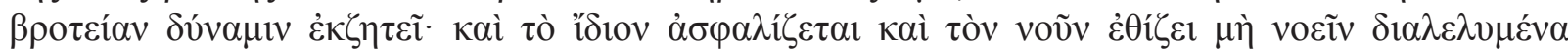

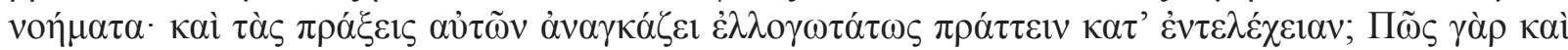

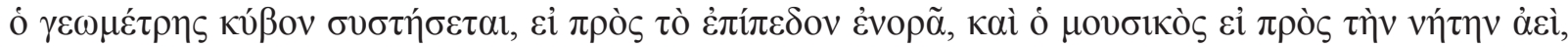

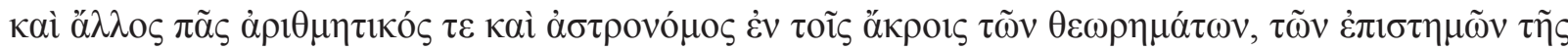

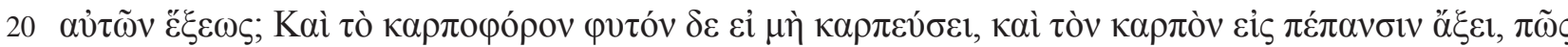

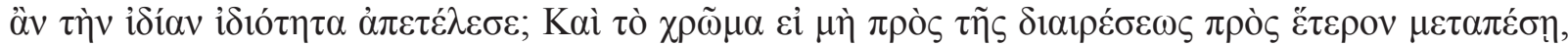

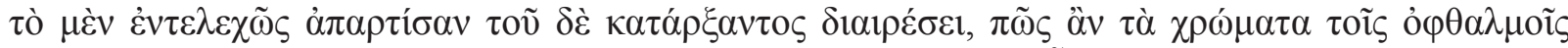

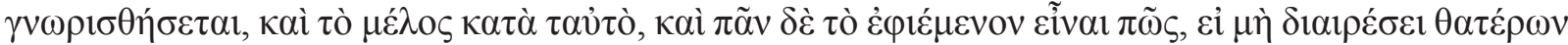

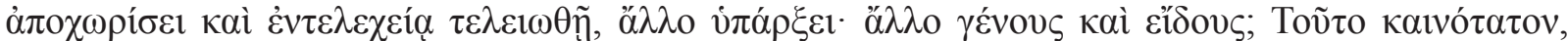

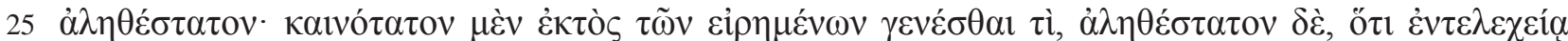

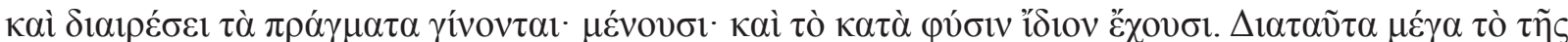

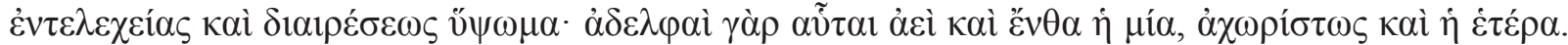

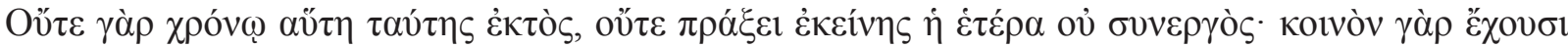

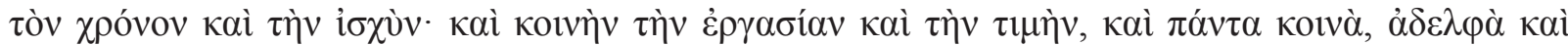

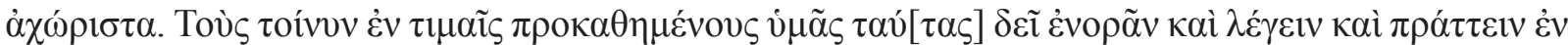

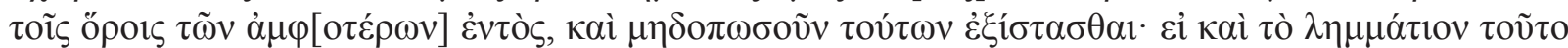

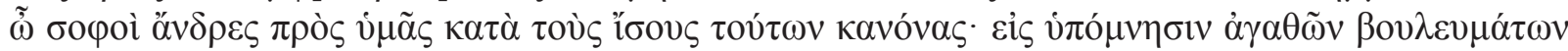

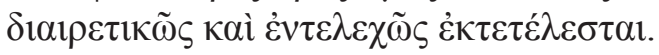

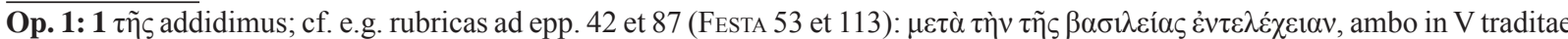

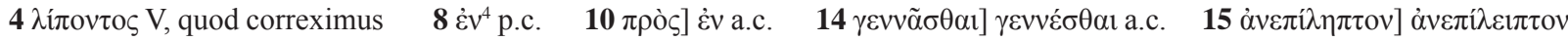

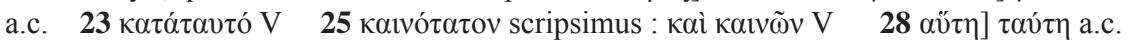


1

By the same: a maxim after the full completeness of imperial rule.

After the dignity of full completeness, one should know that division is closest to it [full completeness] insofar as anything in each [full completeness and division] is complete in every respect. For if existent things are found to be conjoined, their dignity is removed. And should their dignity be absent, the common state of everything produces none of these existent things, but when they are preserved in their dignities, then [5] things in existence truly do exist. And this is so in the natural sciences and in the supernatural ones, in those in-between, in the mathematical sciences, in the logical theorems, in the rhetorical disciplines, in the grammatical ones, in the poetic ones, in the legal ones, in the medical ones, in maxims, in discourses, in deeds, in acts, in elements, in metals, in plants, in animals, in colours, in qualities, in all that is, in everything. For should we divide, we make a collection that seeks also full completeness beginning from [10] division and ending at this one [full completeness] from the other [division] as if from a mother, from her as if from a breath, an animated force of life. How can, then, what is born not come from a maternal cause, and how can what strives to endure not be composed from life-giving incorruption? Division is a mother, a full completeness of things, a life and a soul, and is, as it were, a constitutive, essential incorruption and existence. The person thus seeking full completeness seeks the integrity of his own labour. The person who determines the relations of the ratios ${ }^{1}$ forces the characteristic property of his own free will to be born. [15] What else does the person who preserves the dignity of each of the two things [full completeness and division] do other than seek blamelessness as far as it lies within human reach, strengthen his own characteristics, train his mind not to think loose thoughts, and force $<$ them $>$ to perform their actions most reasonably and in full completion? For how shall the geometrician compose a cube if he looks only at flatness, how shall the musician <compose a melody $>$ if he always looks at the lowest string, and how shall every other mathematician and astronomer <compose their ideas $>$ at the summit of the theorems, <the summit> of the sciences [20] of their very own training? How would the fruit plant fulfill its own characteristic property if it will not bear and ripen its fruit? And if one colour should not change into another by reason of its divisions (the former colour being actually complete, the latter having begun through division), how then shall colours be recognized by the eyes? And $<$ how shall $>$ the melody $<$ be recognized $>$ in the same manner? And how shall everything striving to be, become something else, something else in terms of kind and species, unless through division it separates itself from other things and through full completeness is brought into perfection? This is most novel, this is [25] most true: most novel for something to be born beyond what has been mentioned, but most true since through full completeness and division things come into being, endure, and possess their natural character. Great is, therefore, the exaltation of full completeness and division! For these are sisters always, and where the one is found, the other is inseparably there too. Neither is in time the former apart from the latter, nor is in action the one unhelpful to the other, for they have in common time and power, labour and honour, and everything is to them common, akin and [30] inseparable. Thus you, men who preside in honours, must observe and speak and act within the limits of both [full completeness and division], and never ever stand apart from them, insofar as this proposition, o wise men, has been distinctly and completely created for you through these same rules [of completion and division], as a notice ${ }^{2}$ of good counsels.

\footnotetext{
The puzzling expression $\sigma \chi \varepsilon ́ \sigma 1 \zeta \tau \tilde{\omega} v \lambda$ ó $\gamma \omega v$ is attested in mathematical contexts (see Nicomachus of Gerasa, Introduction to Arithmetics 2, 24, 7). The translation follows Laskaris' special interest in mathematics. On geometrical proportionality ("ratiobased equality”) in Platonic and Neoplatonic social and political thought, see D. O’ MeArA, Platonopolis: Platonic Political Philosophy in Late Antiquity. Oxford 2005, 101-105, 180, 190-191, 201.

2 Y⿱宀⿻三丨日巾 peror. For the last meaning, see F. Miklosich - J. Müller, Acta et diplomata graeca medii aevi sacra et profana. Vol. 4. Vienna 1871, 36-37 (no. IV), 291, 327-328; F. Ferrari Dalle Spade, Formulari notarili inediti dell'età bizantina. Bollettino dell'Istituto Storico Italiano 33 (1913) 41-126, esp. 61 (no. 33); ep. 19.5-9 (FeSTA 25).
} 


\section{2}

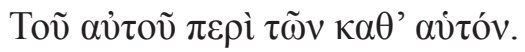

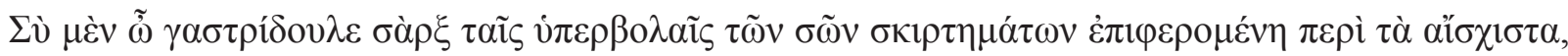

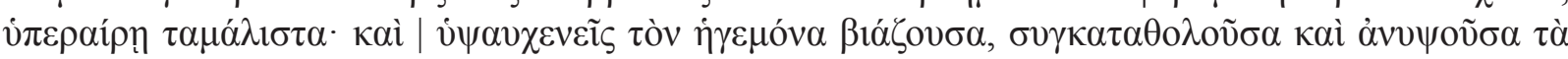

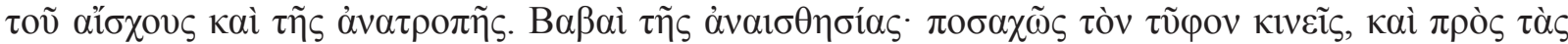

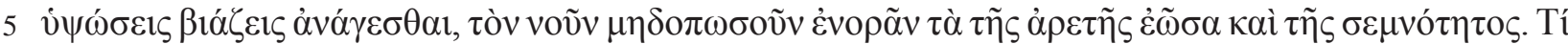

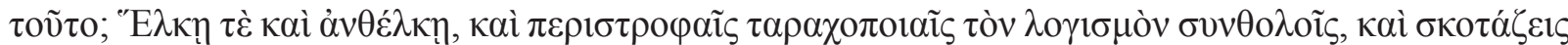

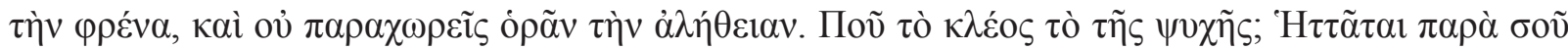

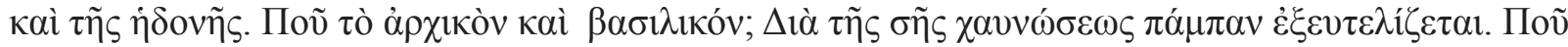

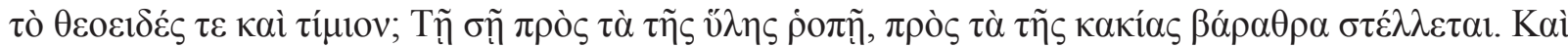

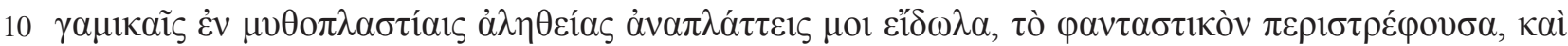

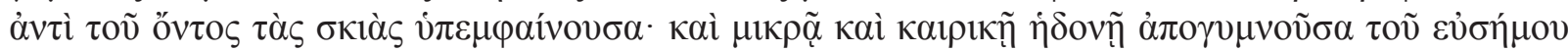

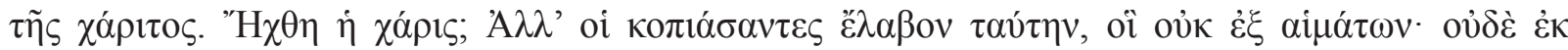

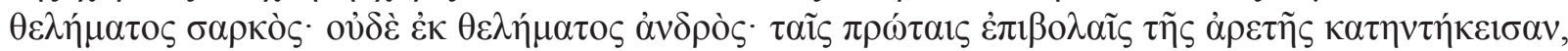

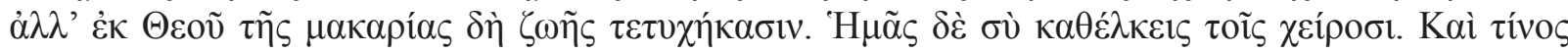

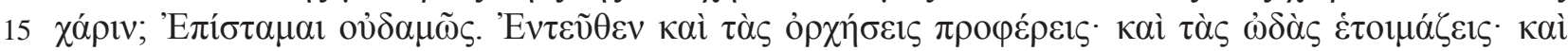

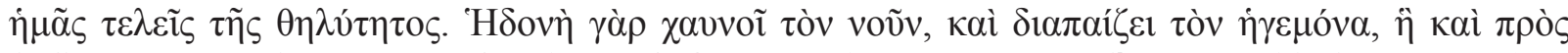

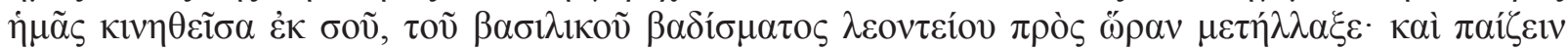

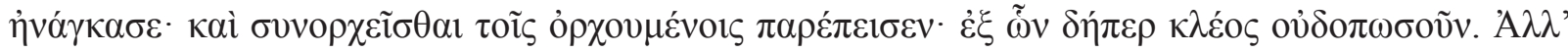

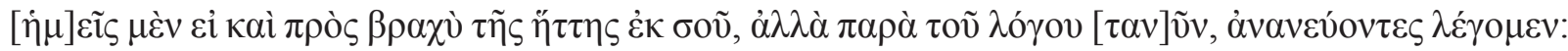

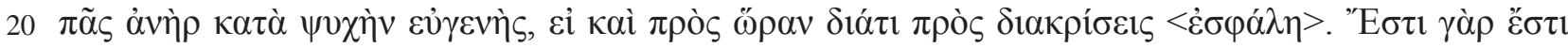

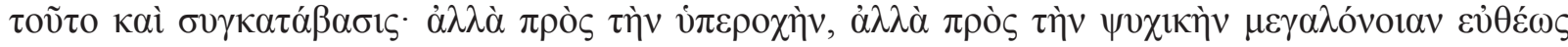

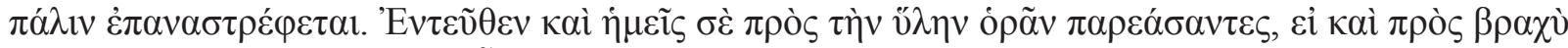

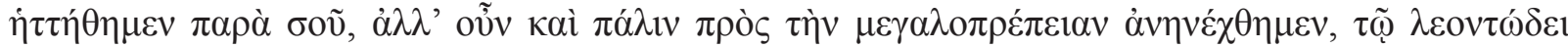

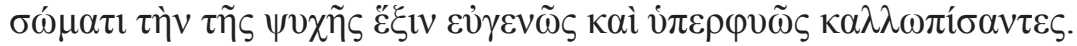

\section{3}

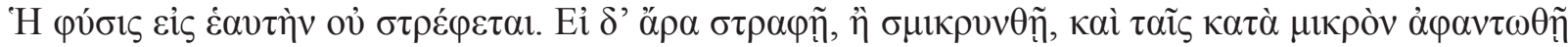

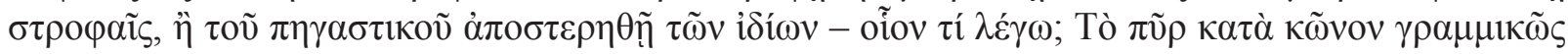

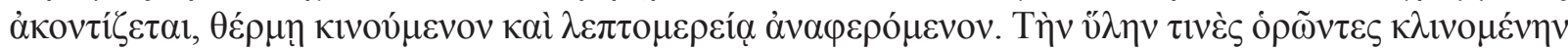

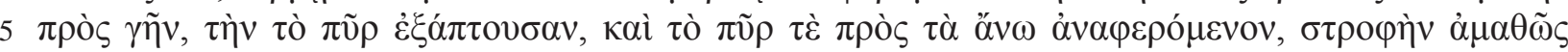
$\tau \tilde{\eta} \varsigma$

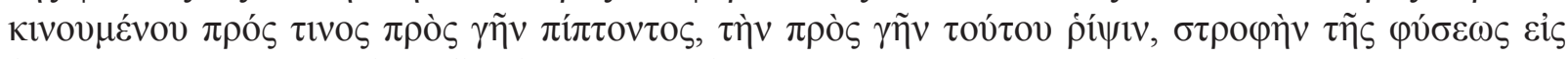
$\dot{\varepsilon} \alpha v \tau \eta ̀ v ~ \kappa \alpha \tau \omega v o ́ \mu \alpha \sigma \alpha v, \dot{\alpha} \mu \alpha \theta \tilde{\omega} \varsigma \pi \lambda \alpha v \eta \theta \dot{v} v \tau \varepsilon \varsigma \dot{\alpha} \mu \varphi \circ \tilde{v}$. 


\section{2}

By the same: about his own affairs.

You, then, belly-enslaved flesh, in rushing towards most shameless things through the excesses of your own stirrings, you pride yourself exceedingly and you arrogantly raise your neck as you force the ruling intellect ${ }^{3}$, agitating and elevating what belongs to shame and ruin. Alas, what senselessness! In how many ways do you stir up vanity and force it to be led towards [5] exaltation, not allowing the intellect ever to observe the matters of virtue and dignity? What then is this? You pull $<$ reason $>$ hither and thither, you dim it through confusing turns, you darken the mind, and you do not allow it to see the truth. Where is the glory of the soul? It is defeated by you and by pleasure. Where is the soul's sovereignty and regality? Through your indolence it is fully debased. Where is its godlikeness and honour? Through your propensity for material affairs it is sent to the abyss of evil. And [10] in marital fictions you invent for me phantoms of truth, confusing my faculty of imagination and presenting me with shadows instead of the actual being ${ }^{4}$, while divesting grace of its prominence through a small and fleeting pleasure. Has grace been granted? Indeed, those who have toiled received it; they have arrived at the first intuitions about virtue not because of $<$ noble $>$ blood, nor because of the will of the flesh, nor because of the will of man, but because they obtained the blessed life from God. But you, flesh, drag us down towards the worst. And for what [15] reason? I do not know at all. Hence, you offer dances and prepare songs and initiate us into effeminacy. For pleasure slackens the mind and laughs at the ruling reason. Incited against us by you, pleasure transformed for some time our leonine imperial gait, forced us to play, coaxed us into dancing together with the dancers - things from which indeed there is no glory whatsoever. But even though we were briefly defeated by you, yet raising now ourselves with the help of reason we say [20]: "Every man is noble in his soul, even if temporarily and due to some cause $<$ he erred $>$ in his decisions." For this, this thing is indeed a moral descent, yet immediately does the soul return again to pre-eminence, to spiritual loftiness. Hence we too negligently allowed you, flesh, to gaze at matter; even if we were defeated by you for a while, nevertheless we have again been elevated to magnificence, nobly and marvelously beautifying the habitual state of our soul through our leonine body.

3

By the same: a proposition.

Nature does not turn upon itself. For if it should turn, it will either be lessened and gradually dis appear because of its own turns, or it will be deprived of the inner source of its own characteristics; but what am I saying? Fire shoots forth geometrically in the shape of a cone, moved by heat and rising due to its fine particles. Some people seeing that matter gravitates [5] towards earth, which kindles fire, and seeing that fire rises up high have ignorantly supposed that rising fire is a turn of nature upon itself. Similarly, should a stone be tossed towards the sky by someone and fall to the earth, people called the throwing of the stone towards earth a turn of nature upon itself, having been ignorantly deceived as to both phenomena.

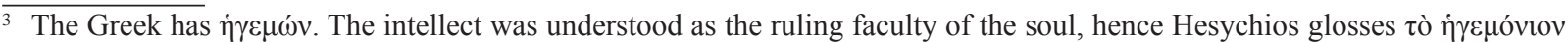

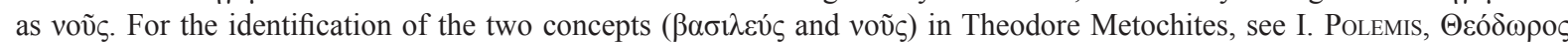

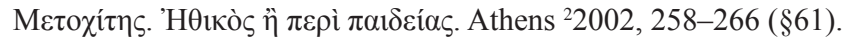

4 This image ultimately goes back to Plato, Republic 514a-520a.

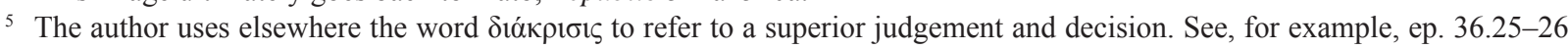
(FESTA 45), ep. 38.11-12 (FESTA 48), which is a reference to the "discerning fire" of trial by ordeal; Moral Pieces §I (255.21-24 Angelov).
} 


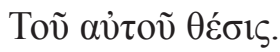

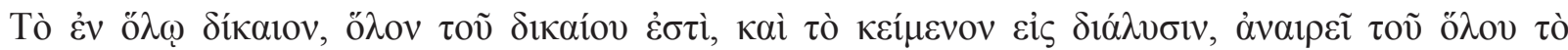

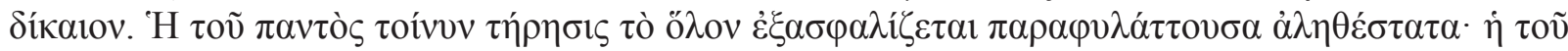

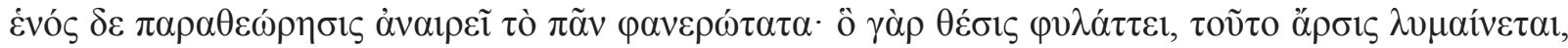

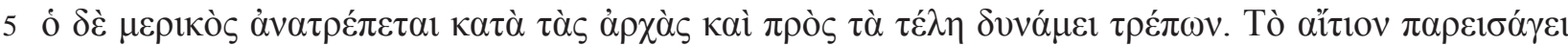

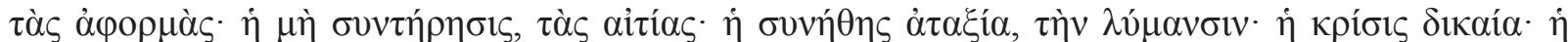

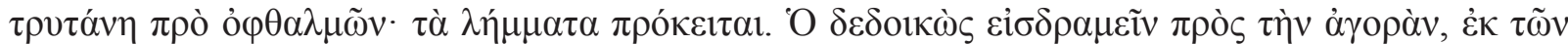

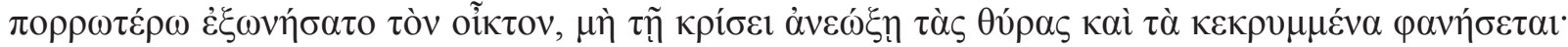

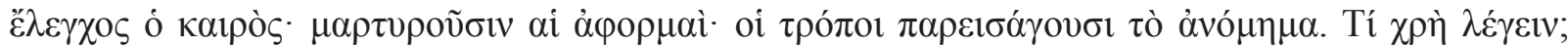

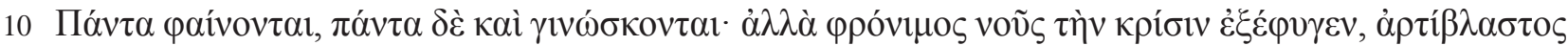

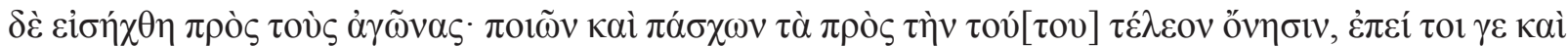

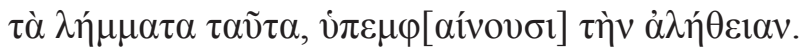

\section{5}

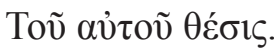

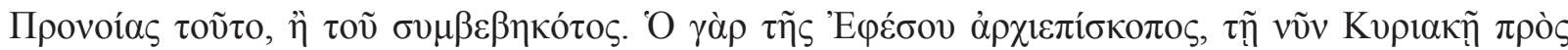

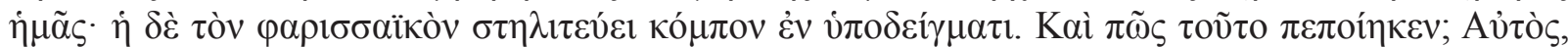

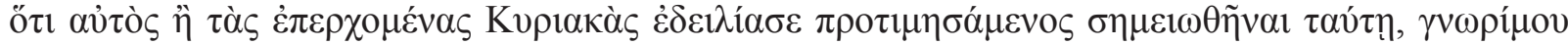

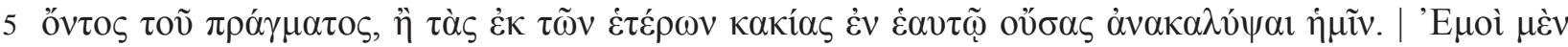

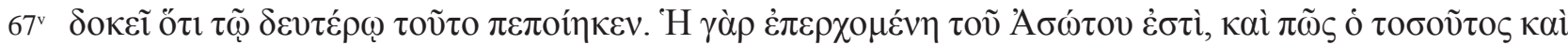

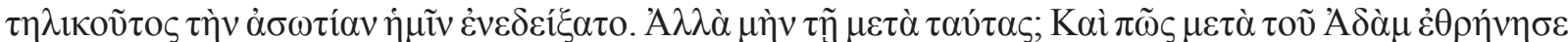

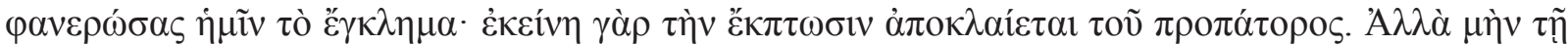

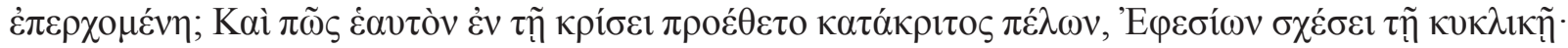

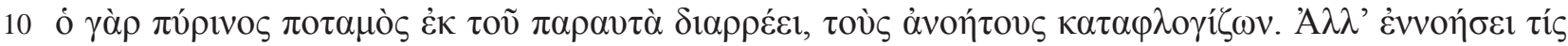

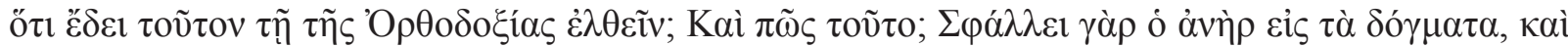

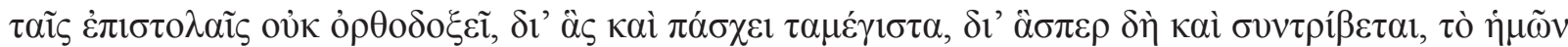

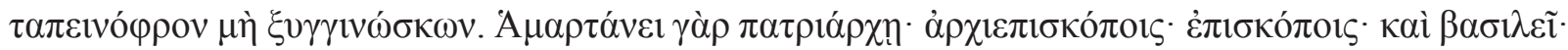

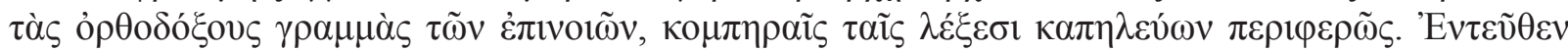

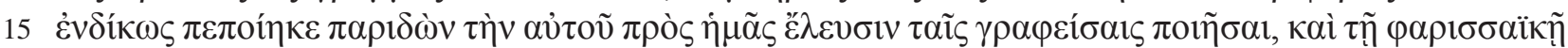

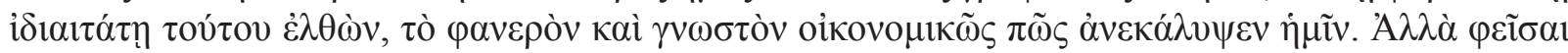

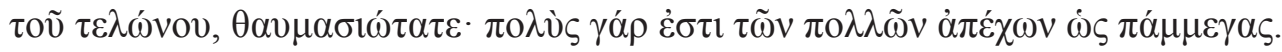

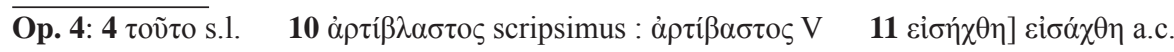

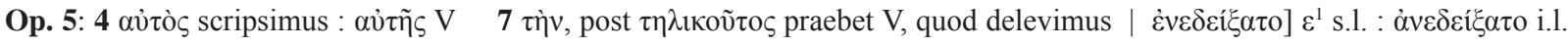

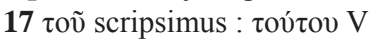


By the same: a thesis.

What is just as a whole belongs wholly to what is just, and what is subject to dissolution removes the justness of the whole. The preservation, then, of everything secures the whole, guarding it most truly. The neglect of one thing removes most manifestly everything, for what affirmation safeguards, negation harms [5], while the partial man is diverted in the beginning and is potentially directed towards the end. Cause introduces the occasions, non-preservation introduces disputes, habitual disorder introduces ruin; the judgement is just, the scale is before our eyes, the propositions are laid out. The person who is afraid to rush to the market has purchased his pity from farther away, lest he should open the gates of his mouth ${ }^{6}$ through his judgement and hidden things should become apparent. Time is the test, occasions testify to this, people's conduct introduces transgression of the law. What is there to say? [10] All things are apparent, all things are indeed known. But the prudent mind has escaped judgement, while as a newly sprouted plant he has been brought to the contests, doing and experiencing things that are to his perfect profit, because these propositions here present the truth.

\section{5}

By the same: a thesis.

This thing happened by providence rather than chance. The archbishop of Ephesos came to us on the present Sunday which denounces pharisaic boasting through an instructive example. And how did he do this? He himself did so, because he either was afraid of the following Sundays, preferring to be marked by this Sunday [5] once the incident is known, or he was afraid of revealing to us the evils of the other Sundays innate in him. It appears to me that he did this for the second reason. For next Sunday is that of the Prodigal Son - and how a man so great and old has demonstrated his prodigality to us! But then what about the Sunday following these two? How he mourned together with Adam, revealing to us his crime, for that Sunday laments the Fall of our forefather! But what about the following Sunday? ${ }^{7}$ How he showed himself being condemned on Judgement Day by the circular state of the Ephesians ${ }^{8},[10]$ for the fiery river immediately flows forth burning down fools! But will someone think that he should have come on the Sunday of Orthodoxy? And how so? The man errs in his doctrines and does not keep to orthodoxy in his letters, on account of which he suffers greatly, on account of which he is crushed by contrition, not being aware of our humility. For he sins against the patriarch, the archbishops, the bishops and the emperor, in that he falsifies the orthodox outlines of concepts through boastful words spoken in a roundabout manner. Therefore, [15] he rightly forewent making an appearance before us on the described Sundays. And having arrived on the Pharisean Sunday so characteristic of him, he revealed to us somehow by divine dispensation what is obvious and known. But indeed, show consideration for the Tax Collector ${ }^{9}$, o most wondrous man, for he is mighty in standing apart from the multitude, being truly the greatest!

\footnotetext{
${ }_{6}$ On the metaphorical meaning of "gates" as "lips," see Laskaris' explication of the proverbial phrase "gates of the wise" as "lips of the wise" in Natural Communion VI 10 (PG 140, 1394AB). He used the phrase autobiographically in his Satire of the Tutor

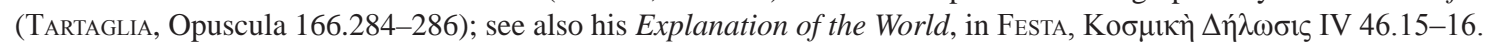

7 Theodore inverts here the liturgical order of the Sunday of the Last Judgement and the Sunday of Forgiveness.

8 "Circular state of the Ephesians": see the analysis of Essay 5 below.

9 That is, Laskaris himself: see the analysis below.
} 


\section{6}

Toṽ $\alpha \dot{\tau} \tau o \tilde{~} \gamma v \omega ́ \mu \eta$.

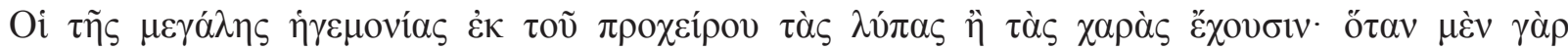

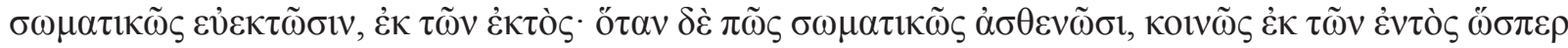

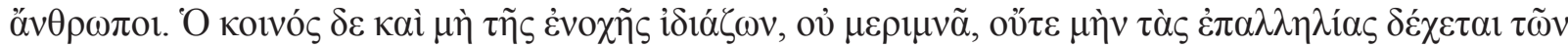

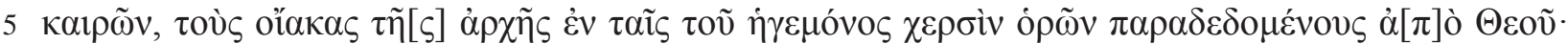

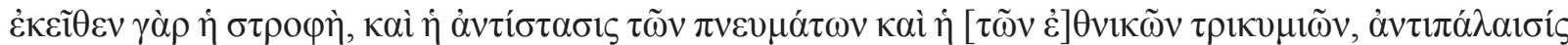

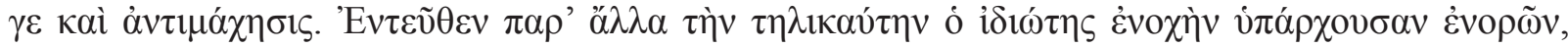

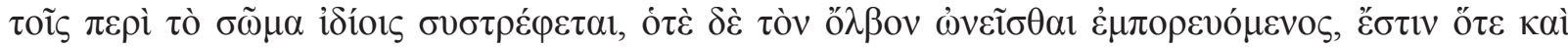

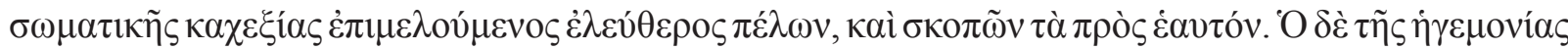

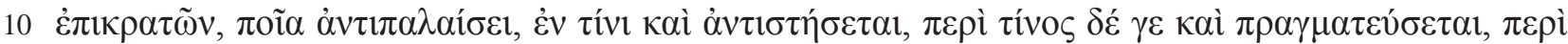

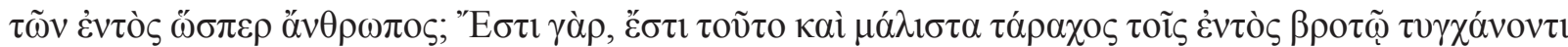

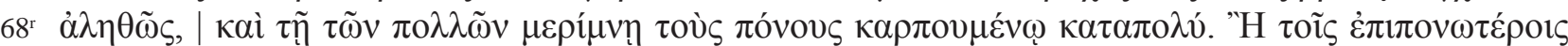

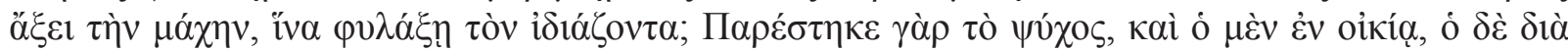

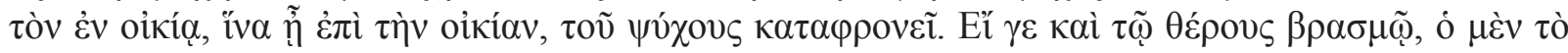

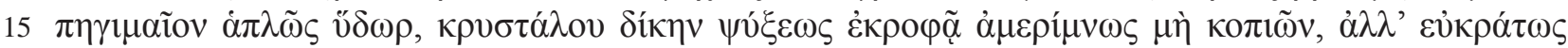

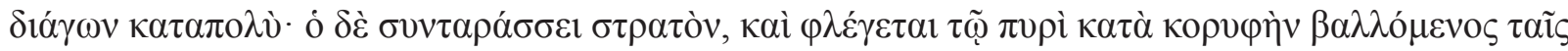

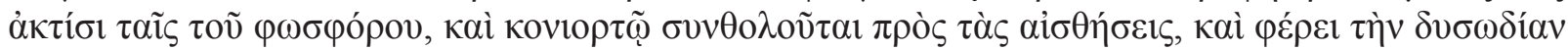

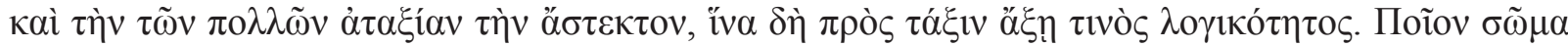

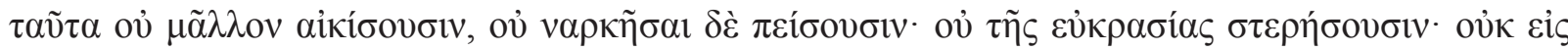

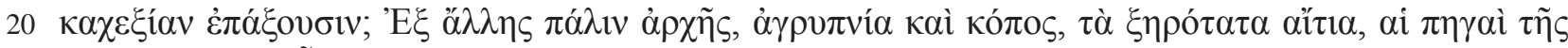

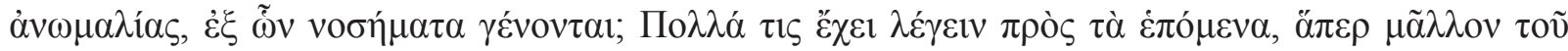

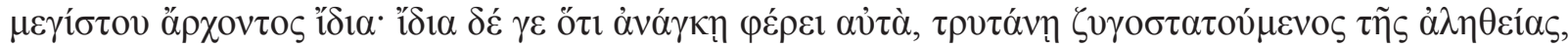

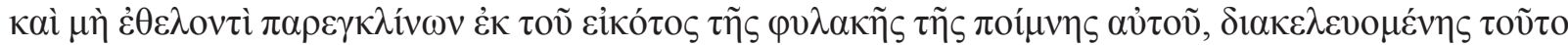

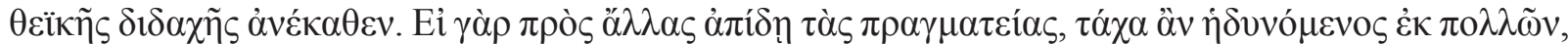

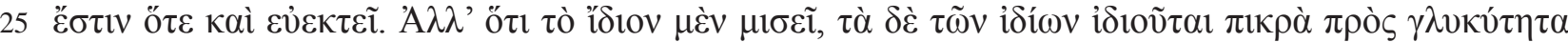

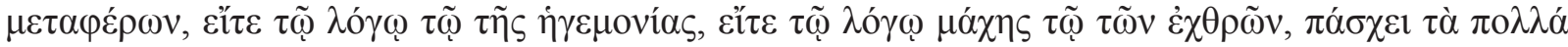

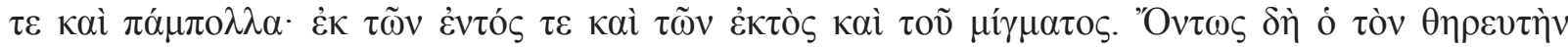

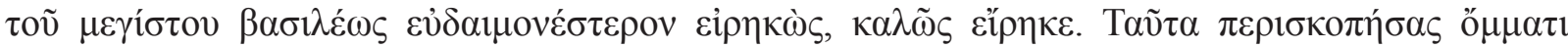

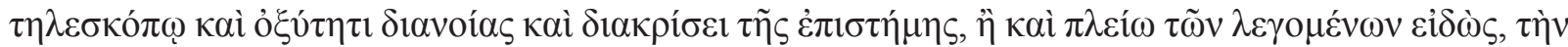

$30 \gamma v \omega ́ \mu \eta v \dot{\varepsilon} \xi \dot{\varepsilon} \theta \varepsilon \tau$.

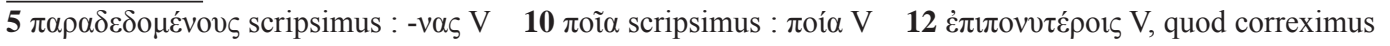
quod correximus

$15 \dot{\varepsilon} \kappa \rho \rho о \varphi \tilde{\alpha} \mathrm{V}$, 


\section{6}

By the same: a maxim.

Rulers of great authority readily experience sorrows rather than joys. When they are well bodily, they do so from the outside, but when for some reason they are unwell bodily, they commonly do so from the inside as human beings do. But the commoner who is not characterized by having a public duty worries not, nor does he understand the alternating succession [5] of critical times, seeing that the helm of government has been placed by God into the hands of the ruler. For there lies the wrestling twist, the opposition to the winds, the resistance to and struggle against the foreign storms. Here again, the private man, who sees that such a great public responsibility is placed elsewhere, turns to the personal care of his body, sometimes when profiting in the purchase of material wealth, sometimes when taking care of his bodily illness because he is free and attends to his own affairs. [10] But against what shall the holder of authority wrestle, what shall he confront, with what shall he concern himself? With his internal condition as a human being? For this, this is very much an upheaval to the internal condition for him who is truly mortal and who reaps much toil because of his care for the many. Or shall he lead the battle against quite toilsome affairs in order to protect the private individual? For the cold of winter has arrived; and the latter staying in his house disregards the cold, while the former does so for the sake of the man in the house, so that he can stay in his house. In the heat of summer, the private individual gulps [15] down with ease spring water as if it were ice in order to cool himself insuciently, not exerting himself but living quite healthily. But the ruler stirs up an army, is parched by fire being struck on his head by the rays of the light-bearer, his senses are blurred by the cloud of dust, and he bears the stench and intolerable disorder of the multitude so as to lead it towards order of a certain rationality. What body will these things not greatly torment, will not force to become numb, will not deprive of wellness, will not [20] lead to illness? Again, do sleeplessness and fatigue - the most desiccating causes, the sources of anomaly from which diseases are born-derive from another origin? One can say many things about the consequences that are rather particular to the greatest sovereign — particular in that he inevitably bears them as he weighs with the scale of truth ${ }^{10}$ and does not willingly deviate from his flock's guardianship, as is the right thing to do, because divine teaching has commanded this from the very beginning. For if the ruler considers other occupations, seemingly deriving pleasure from many of them, [25] then it happens that he is healthy. But given that he despises his own interest and makes the bitter cares of private individuals his own, changing them into sweetness, he suffers all too many things from the inside, from the outside and from their mixture, and this either by the very reason of rulership or by the very reason of battle against the enemies. Surely, he who has called the hunter happier than the greatest emperor has said it well ${ }^{11}$. After having examined these things with a far-seeing eye ${ }^{12}$ and with the sharpness of thought and the judgement of knowledge, [30] he expounded the maxim, although he knows more than what has been said.

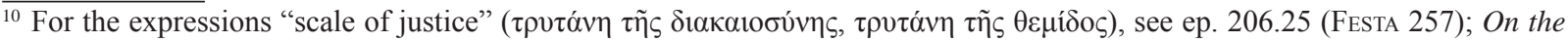

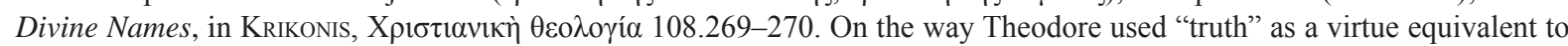
justice, see D. Angelov, Imperial Ideology and Political Thought in Byzantium, 1204-1330. Cambridge 2007, $243-244$.

${ }^{11}$ There might be a faint hint here at a similar passage in Dio Chrysostom's Eubaean Tale (orat. VII 66).

${ }^{12}$ Aristophanes, Clouds 290 ( $\left.\left.\tau\right\rceil \lambda \varepsilon \sigma \kappa o ́ \pi \omega ~ o ̋ \mu \mu \alpha \tau\right)$; hence Blemmydes, Imperial Statue §18, in: I. ŠEVČENKO - H. HungER, Des

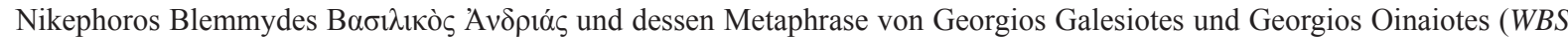
18). Vienna 1986, 48.
} 


\section{THE MANUSCRIPT}

Cod. Vind. phil. gr. 321 (V) (Diktyon 71435) is a miscellaneous codex of small size (ca. $170 \times 120$ $\mathrm{mm}$ ) including mostly rhetorical and epistolographical works of the twelfth and the thirteenth century, along with various grammatical, lexicographical and orthographical treatises, both ancient and Byzantine $^{13}$. The original volume comprises 319 folia of mediocre oriental paper; a remaining set of nine paper folia (320-328) dates from the sixteenth century. The original volume was written by one scribe (with a fluctuating style and the use of different inks) in the last third of the thirteenth century, given that two texts can be securely dated to 1267 (see further below) ${ }^{14}$. Folia 310-319 were detached from the original volume and bound at the end; they belong to earlier sections of the codex.

Along with many other Byzantine manuscripts, V was bought by the Flemish scholar and diplomat Ogier Ghiselin de Busbecq (1522-1592), commonly known as Augerius von Busbeck, while he was residing in Constantinople between 1555 and 1562 as ambassador of the Habsburg monarchy. After long-winded negotiations about the sale, Busbeck presented the acquired codices (272 volumes of his legacy survive today) to Emperor Maximilian II in 1576 shortly before the latter's death. As with all of Busbeck's Constantinopolitan acquisitions, V bears on $\mathrm{f}$. $2 \mathrm{r}$ the note that Busbeck had bought the manuscript in Constantinople. This is not an autograph note, but was probably written by a secretary in the service of Busbeck ${ }^{15}$. Around 1670, Peter Lambeck (1628-1680), chief librarian of the Hofbibliothek, or most probably one of his assistants, added the current pagination to the manuscript $^{16}$. That the volume was already bound when Busbeck acquired it in Constantinople can be inferred from the following: (a) all loose folia were neatly placed at the end of the book before the introduction of the pagination; (b) the set of nine 16th-c. folia had also been added in Constantinople; (c) volumes in the Hofbibliothek were not rebound on a grand scale until the eighteenth century. It is possible that the binding had been removed before transport from Constantinople to Vienna, but Lambeck's pagination is a safeguard that the original state of the codex was not altered then or after. During the major repair project instigated in 1754 by Gerhard van Swieten (1700-1772), then prefect of the Hofbibliothek, the book was bound anew; it was professionally restored in 1912 and $1917^{17}$.

The contents of the original volume are summarily the following ${ }^{18}$ : Euthymios Malakes, orations; George Tornikes the elder, letters and orations (including the funeral oration on Anna Komne-

\footnotetext{
${ }^{13}$ First detailed description of V with extracts from the texts by S. Lambros, O $\beta 1 \varepsilon v v \alpha i ̃ o \varsigma \kappa \tilde{\omega} \delta i \xi$ Phil. graecus CCCXXI. NE 13 (1916) 3-22; full codicological description by H. HunGER, Katalog der griechischen Handschriften der Österreichischen Nationalbibliothek. Band 1: Codices historici, codices philosophici et philologici (Museion. Neue Folge 1.1; 4. Reihe). Vienna 1961, 409-418. Despite the use of V in a number of fairly recent editions (see nn. 19-25 below), no attempt has been made to place the manuscript within an identifiable historical context. The manuscript is easily accessible in digital form via the link http://data.onb.ac.at/rec/AL00116655 (accessed 08-08-2018).

${ }^{14}$ In a few instances we find hands of the fifteenth and early sixteenth centuries writing down short prose or verse texts, and also including rough sketches, for example, f. $263 \mathrm{v}$ (on the last blank page of a quire, two hands of different date have copied verse riddles), $304 \mathrm{r}-\mathrm{v}$, and $309 \mathrm{v}$. It is possible that ff. $302 \mathrm{v}-303 \mathrm{r}$ (a prose passage on John Chrysostom) were also written by different hand, although it is equally possible that it is the main scribe who has copied this text in a densely abbreviated, informal script.

15 On Busbeck's acquisitions in Constantinople and the donation to the emperor see J. Stummvoll (ed.), Geschichte der Österreichischen Nationalbibliothek. Erster Teil: Die Hofbibliothek (1368-1922). Vienna 1968, 71-73 and 119-121. For a biography of Busbeck, see Z. Von MarTels, Augerius Gislenius Busbequius: leven en werk van de keizerlijke gezant aan het hof van Süleyman de Grote. Groningen 1989.

${ }^{16}$ We owe the information on the manuscript's pagination to Prof. Kresten.

17 Hunger, Katalog 418. For the restoration of 1912 see the note on f. Iv signed by Josef Bick (1880-1952), then librarian and later prefect of the Hofbibliothek.

${ }^{18}$ Editions are referred to only for texts published after Hunger's catalogue entry or omitted from it.
} 
ne) ${ }^{19}$; Prokopios of Gaza, selection of letters ${ }^{20}$; John Tzetzes, two poems, as well as the Theogony and the Allegories of the Iliad; Michael Psellos (?), eight letters ${ }^{21}$; the Laskaris dossier (see below); Nikephoros Blemmydes, selection of letters; Manuel Holobolos, orations, a poem, and draft of a letter by the emperor Michael VIII Palaiologos to Pope Clement IV ${ }^{22}$; Longibardos, notes on schedography; various orthographical, grammatical, metrical and lexicographical treatises; Menander, one-verse maxims; Manuel Karantenos, letters, a comparison between rhetoric and philosophy, and other writings ${ }^{23}$; Nikephoros Chrysoberges, orations, including imperial panegyrics of Alexios III and Alexios IV Angelos, a speech addressed to Patriarch John X Kamateros, a letter, and progymnasmata ${ }^{24}$; Nikephoros Basilakes, prose lament on a friend, diatribe against Bagoas, selection of progymansmata ${ }^{25}$; three poems ascribed to Theodore Prodromos, but belonging to the collection of the so-called Manganeios Prodromos ${ }^{26}$; minor texts.

For the present purposes, it is necessary to examine in more detail the Laskaris dossier (unit no. 7 in Hunger's description). The dossier currently comprises 56 folia (59-114). However, three folia, now at the end of the original volume $(310,311,318)$, belong to this unit, adding up to a total of 59 folia. The entire surviving dossier thus consists of the following eight quires: $8(310+59-64+318)$, $8(65-71+311), 2(72-73), 4 \times 8(74-105), 9(106-114)$. The content of the reconstructed dossier is as follows:

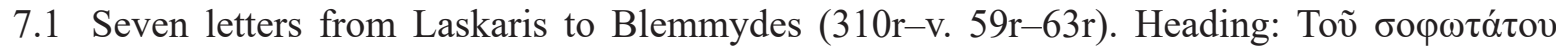

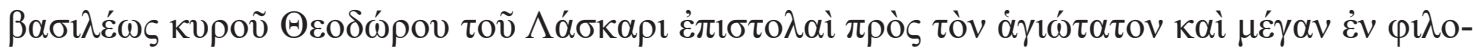

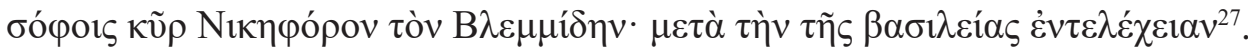

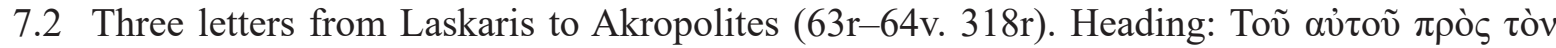

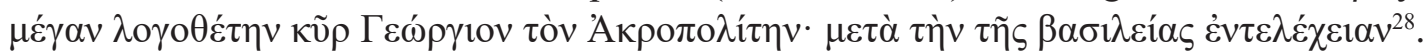

19 See J. DARrouzès, Georges et Dèmètrios Tornikès: Lettres et discours. Introduction, texte, analyses, traduction et notes. Paris 1970, 63, for a survey of the 32 works transmitted in V, and 220-323, for an edition with French translation of the funeral oration on Anna Komnene.

20 A. Garzya, Procopii Gazaei Epistulae. Leipzig 1963; Italian translation and commentary by E. Amato, Rose di Gaza: Gli scritti retorico-sofistici e le epistole di Procopio di Gaza (Hellenica 35). Alessandria 2010.

${ }^{21}$ P. Gautier, Un recueil de lettres faussement attribué à Michel Psellos. REB 35 (1977) 99-106. On the letters in V see also E. N. PapaIoannou, Das Briefcorpus des Michael Psellos: Vorarbeiten zu einer kritischen Neuedition. JÖB 48 (1998) 67-117, esp. 78.

22 On this material, see below nn. 76, 78-80.

${ }^{23}$ See the editions by U. Criscuolo, BollGrott 30 (1976) 139-150; 31 (1977) 103-119; 36 (1982) 123-136; EEBS 42 (19751976) 213-221; 44 (1979-1980) 151-173.

${ }^{24}$ The speech addressed to the patriarch was edited by R. Browning, An unpublished address by Nicephorus Chrysoberges to Patriarch John Kamateros of 1202. Byzantine Studies/Études byzantines 5 (1978) 37-68; for an edition of the progymnasmata, see F. Widmann, Die Progymnasmata des Nikephoros Chrysoberges. BNJ 12 (1935-1936) 12-41 and 241-299.

${ }^{25}$ For the Bagoas see A. GARZYA, Nicephori Basilacae Orationes et epistulae. Leipzig 1984; for the monody and the progymnasmata, see A. PIGNANi, Niceforo Basilace: Progimnasmi e monodie (Byzantina et Neo-Hellenica Neapolitana 10). Naples 1983. Both editions are to be used in conjunction with the detailed reviews by W. HöRANDNER, JÖB 36 (1986) 73-88 and D. R. REINSCH, BZ 80 (1987) 84-91. For a corrected text of the progymnasmata with facing English translation see now J. BeneKer - C. A. GiBson, The Rhetorical Exercises of Nikephoros Basilakes: Progymnasmata from Twelfth-Century Byzantium. (Dumbarton Oaks Medieval Library). Washington, DC 2016.

${ }^{26}$ Nos. 1-2 and 21. It was W. HörAnDNER, Theodoros Prodromos: Historische Gedichte (WBS 11). Vienna 1974, 147, who identified the three poems as belonging to the collection preserved in the Marc. gr. XI.22 (Diktyon 70658), a miscellaneous late 13th-century paper codex including almost exclusively works by twelfth-century authors; see the analytical description by E. Mioni, Bibliothecae Divi Marci Venetiarum Codices Graeci Manuscripti. Vol. III codices in classes IX X XI inclusos et supplementa duo continens. Rome 1972, 116-131. For a complete list of the "Prodromic" poems in the Marcianus with tentative dates and available editions see P. Magdalino, The Empire of Manuel I Komnenos, 1143-1180. Cambridge 1993,

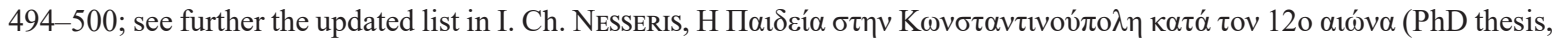
University of Ioannina). Ioannina 2014, II, 467-476.

${ }^{27}$ Epp. 42-48 (FESTA 53-66). The headings are quoted directly from V, thus correcting minor transcription errors of FESTA.

28 Epp. 39-41 (FESTA 113-116). 
7.3 A newsletter addressed to Laskaris' subjects in Anatolia announcing the Treaty of Regina (29

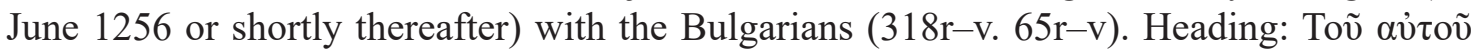

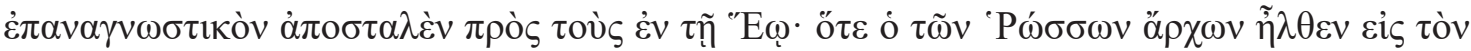

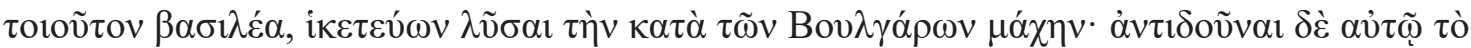

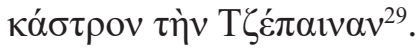

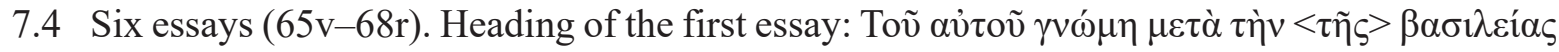
$\dot{\varepsilon} v \tau \varepsilon \lambda \varepsilon_{\varepsilon} \chi \varepsilon 1 \alpha \nu$.

7.5 Eight letters from Laskaris to high church dignitaries in the empire of Nicaea and the Catho-

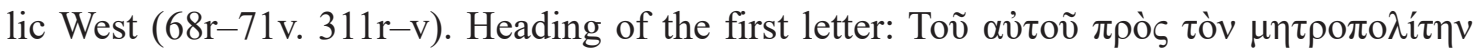

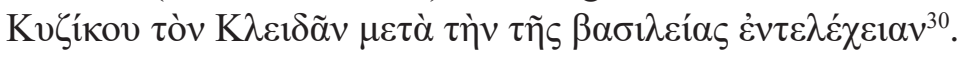

7.6 Two letters to a certain Philip (72r). No heading preserved ${ }^{31}$.

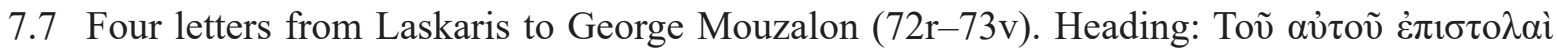

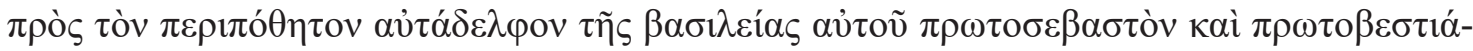

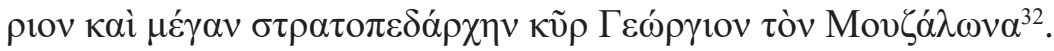

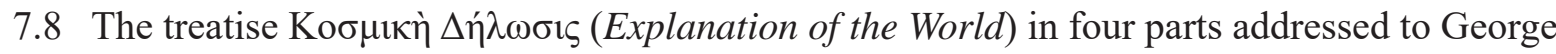

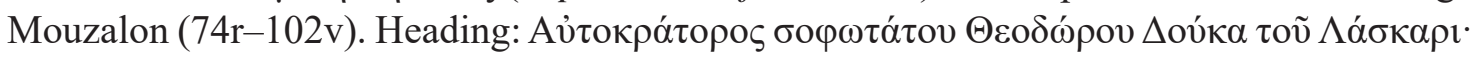

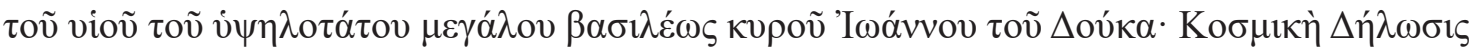

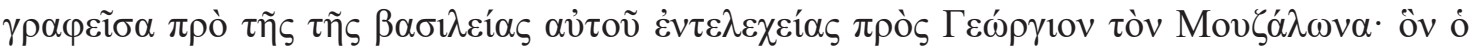

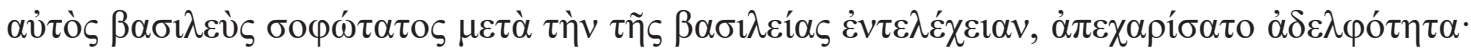

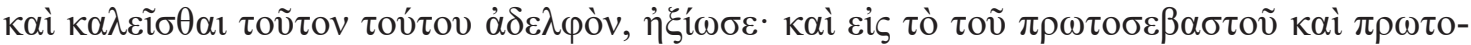

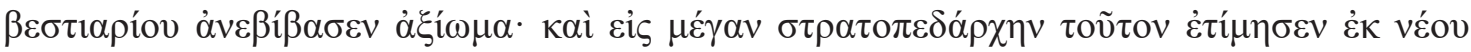

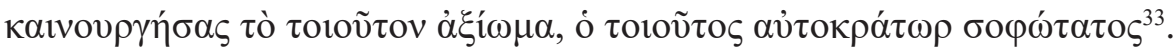

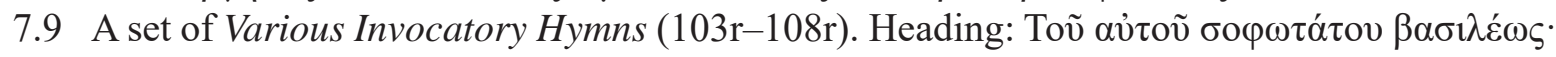

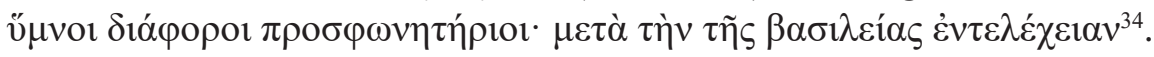

7.10 Letters from Laskaris to Blemmydes and Akropolites $(108 \mathrm{r}-114 \mathrm{v})$. Heading I: Toṽ av่toṽ

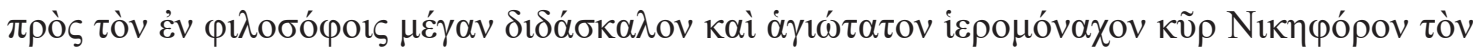

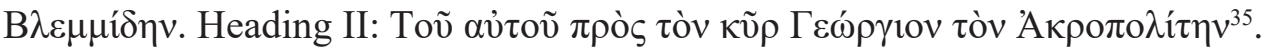

The dossier presents only one textual gap. After $311 \mathrm{v}$ and before $72 \mathrm{r}$ a number of folia diappeared: the text on $311 \mathrm{v}$ breaks off at the end and the text on $72 \mathrm{r}$ lacks its beginning ${ }^{36}$. This gap explains the peculiar presence of quire $72-73$, the only binio in the whole codex.

The works featured in sections 7.1, 7.2, 7,3, 7,4, 7.5, 7.7 and 7.9 were all composed after No-

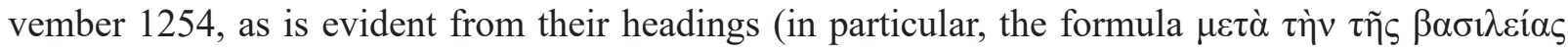
$\dot{\varepsilon} v \tau \varepsilon \lambda \varepsilon \dot{\varepsilon} \chi 1 \alpha v)$ and internal textual evidence. The newsletter on the Peace of Regina in section 7.3 which lacks a heading can be securely dated to 1256. The four letters addressed to George Mouzalon,

${ }^{29}$ Appendix I to FeSTA's edition of the letters found on pp. 279-282. On the Treaty of Regina, see Akropolites, History § 62 (ed. A. Heisenberg, Georgii Acropolitae Opera, I, rev. ed. P. Wirth. Stuttgart 1978, 126-127). The chronology of the treaty

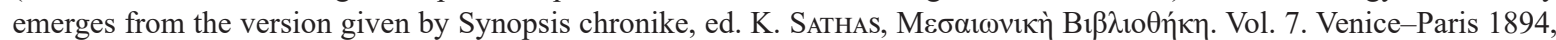
523.31-525.5; see R. MACRIDES, George Akropolites: History. Oxford 2007, 304-305 n. 3.

${ }^{30}$ The sequence of the letters as transmitted in V is the following: epp. 141, 131, 142, 144, 146, 143, 147, 145 (Festa 198-200, 183-185, 201-202, 205-206, 208, 202-204, 206-207). The headings of epp. 131, 142 and 143 feature the chronological

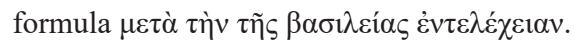

31 Epp. 148-149 (FESTA 212-213).

32 Epp. 211-214 (FESTA 263-266).

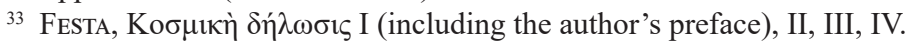

34 The seventeen prose hymns have so far remained unedited. Antonia Giannouli is currently preparing a critical edition accompanied by a full study of these quite unique hymnic texts.

${ }^{35}$ Epp. 1, 3, 9-11, 14-15, 26, 33, 36, 40-41 (all addressed to Blemmydes), 49, 56-58, 60, 67, 69, 71-72, 76, 81-82, 85 (all addressed to Akropolites) (FESTA 1-53, 67-112).

36 The gap was detected by FeStA, vi. The relevant letters are epp. 145 and 148 (FESTA 207 and 212). 


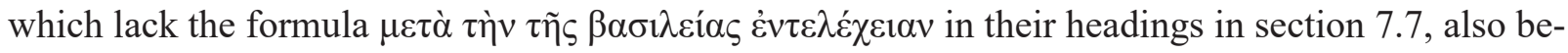
long to the period after 1254. They include a letter describing the flight to Nicaea of the Seljuk sultan 'Izz al-Dīn Kay Kāwūs II in early 125737; and also a letter congratulating Mouzalon on his marriage to Michael Palaiologos' niece Theodora Palaiologina (the future literata and manuscript copyist Theodora Rhaoulaina Palaiologina), a marriage arranged during the reign of Laskaris ${ }^{38}$. In addition, the headings of the four letters mention the titles of protosebastos, protobestiarios and megas stratopedarches, which Laskaris conferred on George Mouzalon after his accession in November 1254, and

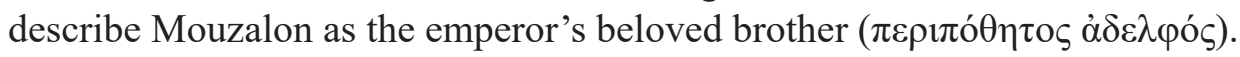

The heading of the Explanation of the World (section 7.8) also mentions the three titles of Mouzalon and the bestowment of "brothership" on Mouzalon, but at the same time states that the work was written in the period $\pi \rho$ ò $\tau \tilde{\eta} \varsigma \tau \tilde{\eta} \varsigma \beta \alpha \sigma i \lambda \varepsilon i \alpha_{\varsigma} \varepsilon \dot{\varepsilon} v \tau \varepsilon \lambda \varepsilon \chi \varepsilon i \alpha_{\alpha}$. Clearly, the Explanation of the World, a quadripartite treatise discussing diverse subjects, was published in an edition prepared after the accession of Laskaris. The four parts were composed separately and at different times. The first and the second part discussing, respectively, the elements and heavens seem to predate his rule (hence

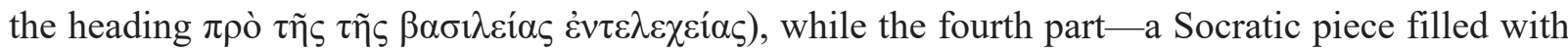
powerful self-irony - dates to his rule as sole emperor, for the author refers to himself as having been crowned by God. The third part was at least heavily revised, if not composed, during his rule ${ }^{39}$. The heading of the treatise on $\mathrm{f}$. 74r is followed by a pinax of the work's four parts with their individual distinct titles (see fig. 1) ${ }^{40}$. After the pinax, the scribe has drawn a decorative band, in whose middle he has placed the abbreviated title of the first part: "First discourse of Explanation of the World"

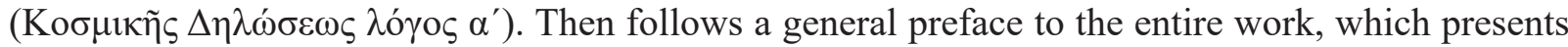
to Mouzalon its overall aim and summarizes the content of each of the four parts ${ }^{41}$. Each part is fully titled by the appropriate heading, the wording of which is identical to the headings in the pinax ${ }^{42}$. All of this suggests that the scribe of V copied the text from a manuscript that had the heading and the pinax on one page, followed on the next two or three pages by the preface to Muzalon (possibly without a title), which was in turn followed on a new page by the main text with the full title of the first chapter.

The letters to Blemmydes and Akropolites copied in sections 7.1 and 7.2 of $\mathrm{V}$, respectively, mirror the arrangement of Laskaris' letters transmitted in the Laur. Plut. 59.35 (L), a miscellaneous paper codex of the first quarter of the fourteenth century containing the letters of Synesius and other texts ${ }^{43}$. This substantial epistolary collection (39r-178r), prefaced by Laskaris' teacher George

37 Ep. 214 (Festa 265-266); see D. Angelov, Theodore II Laskaris on the Sultanate of Rum and the Flight of 'Izz al-Dīn Kay Kāwūs II. Journal of Turkish Studies 36 (2011) 26-43 (= In Memoriam Angeliki Laiou, eds. C. Kafadar and N. Necipoğlu).

${ }^{38}$ Ep. 212 (Festa 263-264). On the marriages arranged by Laskaris, see GeOrge PaChymeres, Relations historiques, I, ed. A. FAILler. Paris 1984, 41.10-11, 153.21-155.5; MACRIDES, George Akropolites 27.

${ }^{39}$ See the authorial statement in the fourth part titled On What Is Unclear, or A Testimony that the Author is Ignorant of Philos-

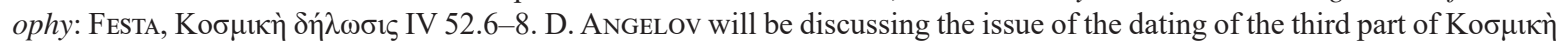
$\Delta \eta \dot{\lambda} \omega \sigma \mathrm{s}$, , a work entitled Representation of the World, or Life, in an appendix to his forthcoming biography of Theodore Laskaris. Suffice it to say here that M. Andreeva. Polemika Theodora II. Laskaria s Nikiforom Vlemmidom. Mémoires de la Société royale des sciences de Bohême, classe des lettres, année 1929. Prague 1929, 1-36 dated the work to the reign of Laskaris on the basis of its content.

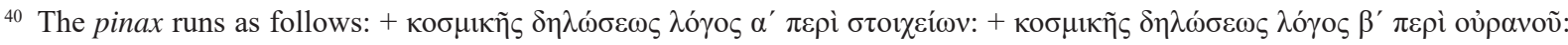

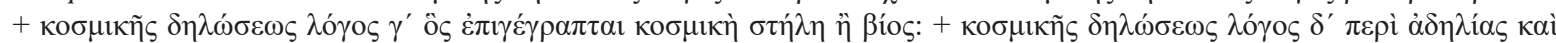

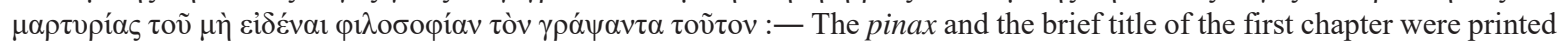

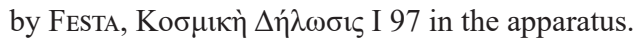

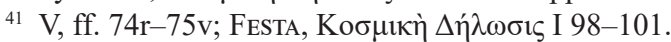

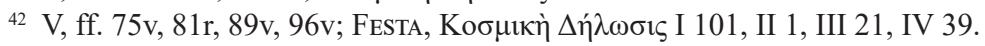

${ }^{43}$ For a good presentation of the contents and basic codicological information see now A. RieHLe, Theodoros Xanthopulos, Theodoros Metochites und die spätbyzantinische Gelehrtenkultur: Zu einem unbeachteten Brief im Codex Laur. Plut. 59.35 
Akropolites $^{44}$, is organized according to addressees, the first two being Blemmydes and Akropolites ${ }^{45}$. The headings of the letters to these two addressees (as well as to other recipients) attribute them to a period before the embassy of the marquis Berthold of Hohenburg to the Nicaean court, which took place in the autumn of 1253 and may have lasted until early $1254^{46}$. The makeup of Laskaris' letter collection in L, and the high probability that L circulated in the circle of Theodore Metochites and the Xanthopouloi brothers ${ }^{47}$, makes it certain that this part of the manuscript reflects a lost volume of the authorized edition of Laskaris' works. We shall name this lost manuscript by the siglum $\lambda$.

Sections 7.3 and 7.4 of V are not letters, while sections 7.5, 7.6 and 7.7 are again letters grouped by recipient as in L. They are followed by the Explanation of the World (section 7.8) and a set of seventeen prose hymns (section 7.9) to the Trinity, Christ, the Holy Cross, the Mother of God, the Angels, John the Forerunner, three apostles and various - mostly military - saints. The hymns are religious (though not liturgical) in character and have political overtones, for in many of them the author prays for divine protection of his rule and a victory over his enemies. The four letters to George Mouzalon in section 7.7 are not represented by anything similar in L, because this collection does not include any letters addressed to him. Furthermore, the four letters are not included in the substantial collection of sixty-one letters to Mouzalon found in the famous Laur. Conv. Soppr. 627 (C) (Diktyon 15899), a miscellaneous paper codex, written by different hands over a longer period of time (ca. 1250-1270 $)^{48}$. The letter collection copied in C was edited after November 1254 in a manner similar to the Explanation of the World in V. The heading refers to the emperor's "brother" Mouzalon with all three of his post-1254 titles (the same as those mentioned in the heading of Explanation of the World), yet $\mathrm{C}$ includes letters composed before November 1254 marked with the formula "before

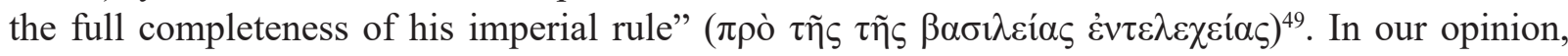
Laskaris' letters to Mouzalon that have survived in $\mathrm{C}$ have been copied from a lost volume of the authorized edition prepared under the emperor's supervision in a manner similar to the L collection. This assumption is strengthened by a colophon (written with red ink) and an epigram found at the

und den Xanthopulos-Briefen im Codex Vat. gr. 112, in: Koinotaton Doron: Das späte Byzanz zwischen Machtlosigkeit und kultureller Blüte (1204-1461), ed. A. Berger - G. Prinzing - S. Mariev - A. Riehle (Byzantinisches Archiv 31). Berlin-Boston 2015, 161-183, esp. 161-163.

${ }^{44}$ For Akropolites' verse preface, see A. Heisenberg, Georgii Acropolitae Opera, II, rev. ed. P. Wirth. Stuttgart $1978,7-9$. Theodore responded to the encomiastic preface of his teacher with an encomium of his own; see TARTAGLIA, Opuscula, 96-108. This is a telling instance of book exchange and composition of accompanying texts in Laskarid Nicaea; for another instance involving Laskaris and Blemmydes see P. A. AGAPITOS, Blemmydes - Laskaris - Philes, in: Byzantinische Sprachkunst: Studien zur byzantinischen Literatur gewidmet Wolfram Hörandner zum 65. Geburtstag, ed. M. Hinterberger - E. Schiffer (Byzantinisches Archiv 20). Berlin-New York 2007, 1-19, esp. 2-6.

45 See L's detailed pinax on f. 41r-v; FeSTA iv-v.

${ }^{46}$ Epp. 1 and 49 (FESTA 1 and 67). Ep. 125.1-2 (FESTA 174) to Andronikos of Sardis clearly refers to the arrival of Berthold

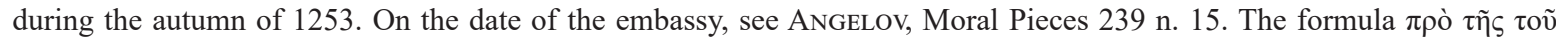

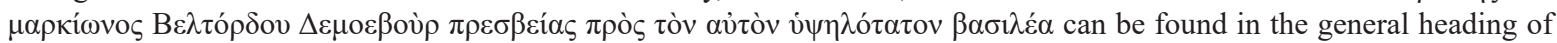
the collection of nine theophilosophical works entitled Sacred Orations and in the heading of each individual work in the collection. The collection has been transmitted in the thirteenth-century Ambros. gr. C 308 inf. (Diktyon 42516) and the fourteenth-century Par. gr. 1193 (Diktyon 50798); see ANGeLov, Moral Pieces 246-247.

${ }^{47}$ See Riehle, Theodoros Xanthopoulos 163-165.

${ }^{48}$ The codex is described by E. Rostagno and N. Festa, Indice dei codici greci Laurenziani non compresi nel catalogo del Bandini. Studi Italiani di Filologia Classica 1 (1893) 172-176; on the date see N. G. WiLson, Nicaean and Palaiologan Hands: Introduction to a Discussion, in: La paléographie grecque et byzantine. Paris 1977, 263-267, esp. 263-264.

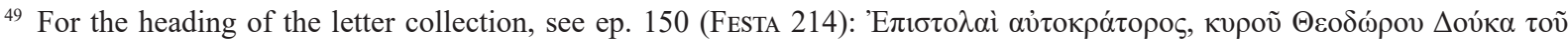

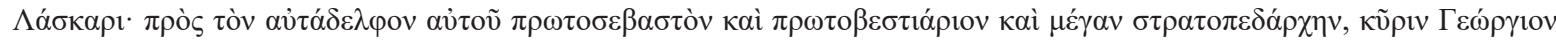

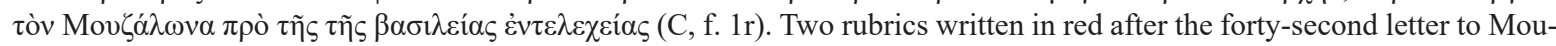

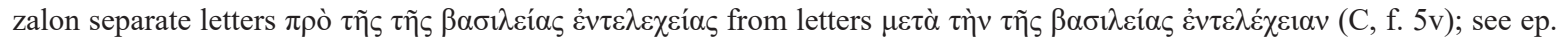
192 (FESTA 239 in the apparatus). 
end of the letters in $\mathrm{C}$ on folio 10v. The colophon was edited by Festa in the apparatus to his edition, yet it has received little notice ${ }^{50}$. The text runs as follows:

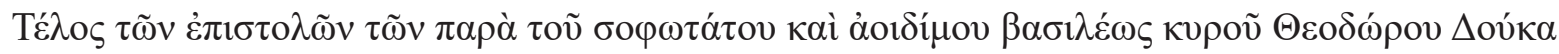

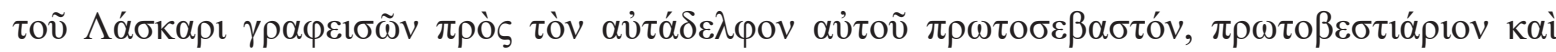

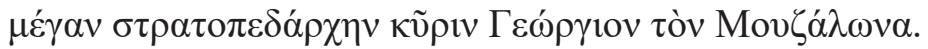

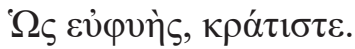

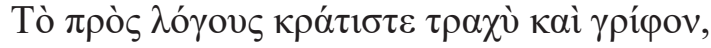

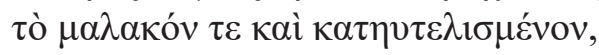

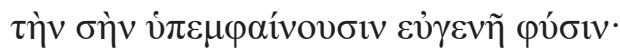

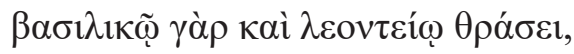

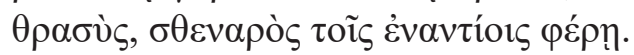

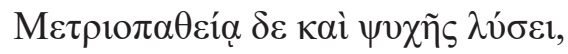

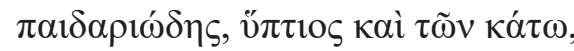

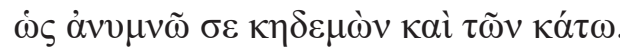

End of the letters written by the wisest and blessed emperor lord Theodore Doukas Laskaris to his own brother, the protosebastos, protobestiarios and megas stratopedarches lord George Mouzalon.

How intelligent $<$ you are $>$, most powerful ruler!

Of your writings, most powerful one, their asperity and riddle-like style, their softness and utter humbleness, clearly hint at your noble nature; for by your imperial and leonine boldness

you boldly and mightily confront the enemies.

In my mediocrity and looseness of soul, childlike, supine and belonging to those of lower status,

how do I praise you, guardian also to those of lower status!

The colophon displays an important difference from the heading of the collection of letters to

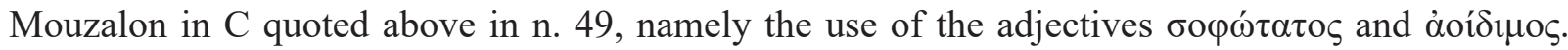

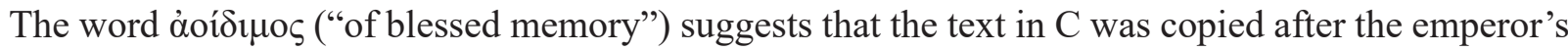
death, and that the scribe added it on his own initiative. Most interesting is the eight-verse poem,

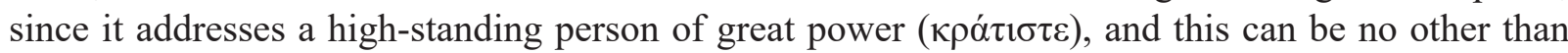
Theodore Laskaris himself. The poem praises Laskaris for specific qualities of his writings and for his courage in confronting his enemies. It reflects Laskaris's self-descriptions and his preoccupation with defining nobility as a moral quality, especially in works addressed to Mouzalon ${ }^{51}$. The way in

${ }^{50}$ FESTA 262. Minor transcription errors or interventions have been corrected with the help of the manuscript. The editor printed the epigram as he found it in the manuscript, i.e. in two columns of four verses each, without commenting on its content. It has been edited here in its proper sequence, since $\mathrm{C}$ copies poetry in the typical Byzantine two-column layout, that is, from the left to the right column; see, for example, the long funerary poem of Michael Psellos on the death of Maria Skleraina, transmitted in C on fols. 17r-19v (ed. L. G. WesterinK, Michaelis Pselli Poemata. Stuttgart-Leipzig 1992, 239-252).

${ }^{51}$ For example, the adjective "leonine" ( $\left.\lambda \varepsilon o ́ v \tau \varepsilon 10 \zeta\right)$ echoes Essay 2. In Representation of the World, or Life addressed to Mouzalon, Laskaris noted that his contemporaries used the word wrongly and applied it to immoral and deceitful people; see Fes-

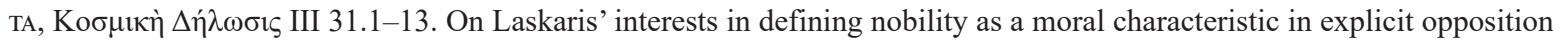
to nobility of blood, see ANGELOv, Imperial Ideology 229-234. 
which the speaker characterizes himself as a person of lower status - note in particular his "childlike" nature and the use of the term "guardian" for his royal addressee-makes it obvious that he is no other than George Mouzalon, very often addressed as "child" or "son" by Theodore ${ }^{52}$. Thus, the poem should be read as a humble laudatory note and was most probably attached to the letter collection, just as Akropolites' poem was attached to the beginning of Laskaris' epistolary collection in L containing pre-1254 letters ${ }^{53}$. The comparison with $\mathrm{L}$ naturally raises the question as to whether the letter collection in $\mathrm{C}$ was copied from an independent volume or whether the dossier was part of a larger manuscript.

The codicological and textual peculiarities of sections 7.1-9 of V noted above strongly suggest that the scribe copied this part of the Laskaris dossier - but not section 7.10 (on which see below) from a manuscript containing an authorized edition of his works. The works included in the collection were either composed after November 1254 or, in the case of the Explanation of the World, redacted after November 1254. We shall refer to this lost manuscript by the siglum $\beta$. The existence of this edition is all the more likely, because Theodore had already prepared a series of manuscript editions of his works before 1254. Surviving volumes of these officially authorized editions are the codices Par. Suppl. Gr. 460 (Diktyon 53202) and Par. Suppl. Gr. 472 (Diktyon 53215) (both parchment, middle of 13th c.). The two manuscripts preserve, respectively, the corpus of Laskaris' ten

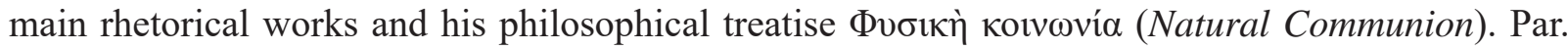
Suppl. Gr. 460 was a deluxe production, one quite unique for including diagrams executed with gold grounding ${ }^{54}$. Cod. Ambros. gr. C 308 inf., a parchment manuscript copied in the later thirteenth century that contains the collection of nine Sacred Orations ( $\Lambda$ ó from a similar deluxe edition prepared in a Nicaean scriptorium ${ }^{55}$. All three authorized editions - the collection of ten secular orations, the treatise Natural Communion, and the collection of nine Sacred Orations - date from the period before Laskaris' accession in November 1254, as indicated by the manuscript headings. The collection in the lost codex $\beta$ must have been prepared after November 1254 , for the headings found in V mention as a chronological marker the "full completeness of his

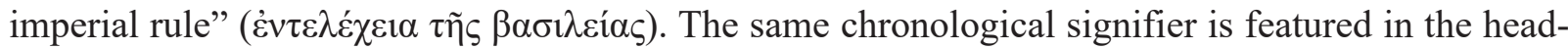

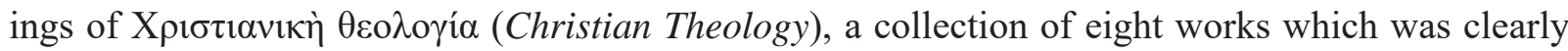
prepared during Theodore's reign and which survives in a few manuscripts, including Vat. gr. 1113 (Diktyon 67744) (a paper codex from the second half of the thirteenth century) ${ }^{56}$.

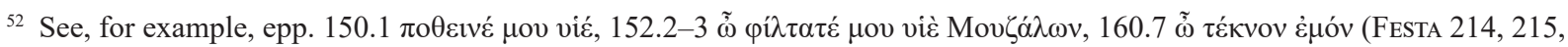
219); Response to Mouzalon 10 (TARTagLia, Opuscula $140.483 \tilde{\omega} \pi \alpha i ̃ ~ \varphi i ́ \lambda \tau \alpha \tau \varepsilon)$.

${ }^{53}$ For another instance of a poem of thanks accompanying a text sent, see above n. 44.

${ }^{54}$ M. Rashed, Sur les deux témoins des œuvres profanes de Théodore II Lascaris et leur commanditaire (Parisinus Suppl. Gr. 472; Parisinus Suppl. Gr. 460). Script 54 (2000) 297-302 has suggested on the basis of the strikingly similar layout of the text of the two manuscripts that they come from the same scriptorium. On the lost portrait of Theodore Laskaris once attached to Par. Suppl. Gr. 460, see C. Förstel, Auf den Spuren eines verschollenen Bildnisses Kaiser Theodors II. Nea Rhome 6 (2009) 445-449. Unfortunately, no full codicological description of Par. Suppl. Gr. 472 exists; for a basic description and reconstruction of its current disordered and lacunose state see Ch. AsTRUC, La tradition manuscrite des œuvres oratoires profanes de Théodore II Lascaris. TM 1 (1965) 393-404, esp. 400-402.

${ }_{55}$ For this argument, see ANGelov, Moral Pieces 251-252; for a codicological description of the Ambrosianus, see M. PALÉOLogou, Deux traités inédits de Théodore II Doucas Lascaris. Byzantina 27 (2007) 51-90, esp. 60-63.

${ }^{56}$ Seven of the eight treatises of the collection Christian Theology are attributed by their headings to the period "after the full

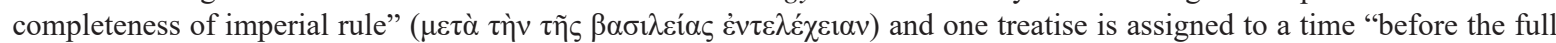

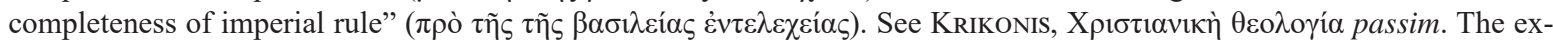
ceptional work (see ibid. 109 and the apparatus) written "before the full completeness of imperial rule" is the fifth discourse of Christian Theology, a Trinitarian philosophical treatise that had been the opening work of the collection Sacred Orations. According to their headings, all nine Sacred Orations date to the period "before the embassy of the marquis Berthold von

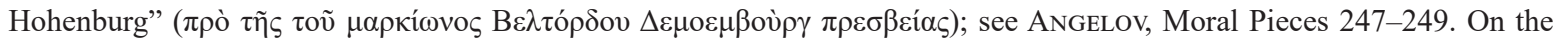

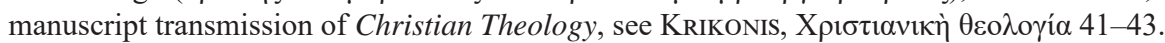


The letters addressed to different recipients and the six essays in codex $\beta$ (sections 7.1-7 of V) were largely structured in the manner of $\lambda$. Quite possibly Laskaris' encomium on Saint Tryphon

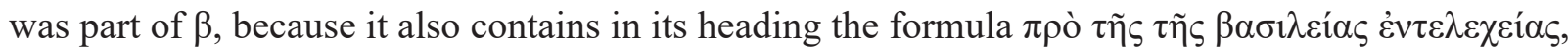
just like the heading of the Explanation of the World. Just as the scribe of $\mathrm{V}$ drew a decorative band before the heading of Explanation of the World and between its pinax and the general preface (f. 74r, fig. 1), so the fourteenth-century copyist of the encomium on Saint Tryphon drew a decorative band before the heading in an effort to imitate the exemplar ${ }^{57}$. Codex $\beta$ thus included at its end (sections 7.8-9 of V) the Explanation of the World and the Invocatory Hymns, and most probably the encomium on Saint Tryphon in this order. If prepared in the size and layout of the Par. Suppl. Gr. 472 (page size: $277 \times 210$; written space size: $173 \times 128$; 19 lines per page, 116 folia with substantial lacunae $\left.{ }^{58}\right)$, this text would have amounted to approximately $108-118$ folia in size. The gap between $311 \mathrm{v}$ and $72 \mathrm{r}$ in $\mathrm{V}$ (i.e. between sections 7.5 and 7.6), along with the misplaced folia 310-319, was already there when Busbeck bought the manuscript in Constantinople since the book had been bound at an earlier date. Therefore, it is probable that $\operatorname{codex} \gamma$, as we shall call the exemplar of the Mouzalon collection in $\mathrm{C}$, was actually part of $\beta$, following the letters of Laskaris to high church dignitaries (section 7.5). Then must have followed a few letters of Laskaris to other persons related to him, like the mysterious Philip (section 7.6), and the very last letters to Mouzalon (section 7.7). The text in $\mathrm{C}$ of the letters to Mouzalon, if recalculated to fit the size of the Par. Suppl. Gr. 472, would have amounted to about 30 folia. Thus, the lost $\beta$ would be a manuscript of approximately 138-148 folia, not much larger than the Par. Suppl. Gr. 472 with its 116 folia plus a loss of approximately 20-25 folia ${ }^{59}$. One can easily imagine manuscript $\beta$ to have been an expensive production prepared with care by the author with the assistance of a secretary. It would have been decorated with ornamental headpieces and, just like Par. Suppl. Gr. 472 (not a deluxe manuscript, but certainly a costly product), would have been made of parchment and would have featured plenty of headings and initials in red ink.

Of a different origin is section 7.10 that transmits letters to Blemmydes and Akropolites without

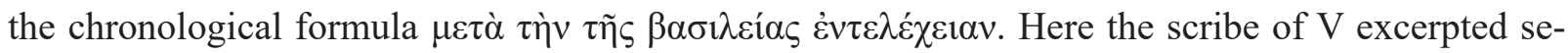
lectively letters to Blemmydes and Akropolites that he found in the epistolary collection of the pre1254 letters, of which $\mathrm{L}$ is the sole surviving manuscript. A comparison of the heading of the letters to Blemmydes copied in section 7.10 of $\mathrm{V}^{60}$ with the equivalent unit in $\mathrm{L}^{61}$ shows that the epithets of Blemmydes ("great teacher among the philosophers and holiest hieromonk") are identical, but the authorial and chronological formulas found in $\mathrm{L}$ are omitted in $\mathrm{V}^{62}$. The text of the letters as trans-

${ }^{57}$ The encomium was copied on fols. $321 \mathrm{r}-327^{\mathrm{a}} \mathrm{v}$ of the eleventh-century Vat. gr. 516 (Diktyon 67147) (containing homilies by John Chrysostom). The eight folios constitute a separate quire bound at the end of the manuscript during the 14th century.

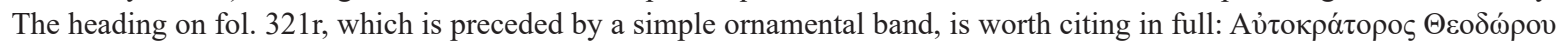

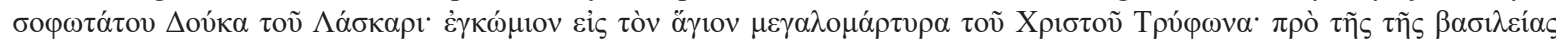

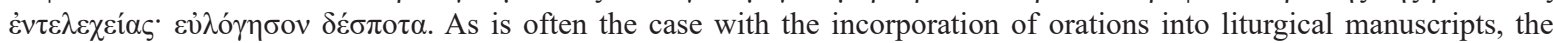
scribe has added the typical formula signalling the beginning of a reading by asking the officiating priest to offer a blessing (on a similar case with an oration of Nikephoros Bemmydes see AGaPiTos, Blemmydes - Laskaris - Philes 13). The text has been edited by H. Delehaye, Acta Sanctorum Novembris IV. Brussels 1925, cols. 352-357. For a description of the Vatican manuscript, see R. Devreesse, Codices Vaticani graeci. Vol. 2: Codices 330-603. Vatican City 1937, 372-373.

58 AstruC, La tradition manuscrite 401; RaSHED, Sur les deux témoins 298.

59 For the lacunae in Par. Suppl. Gr. 472 see Tartaglia, Opuscula, ix (gaps in nos. 1, 2, 3, 9, and the whole of 10).

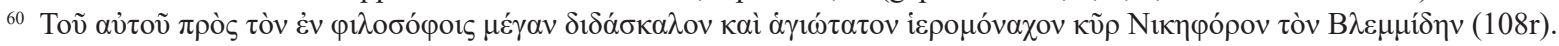

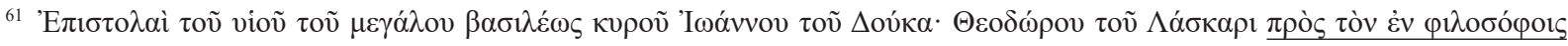

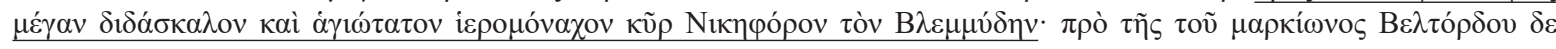

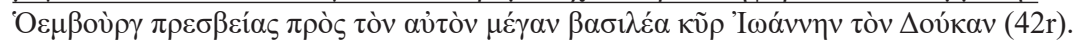

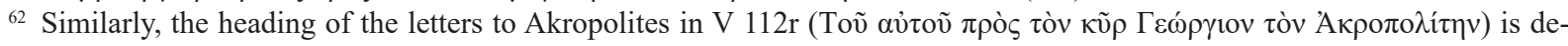

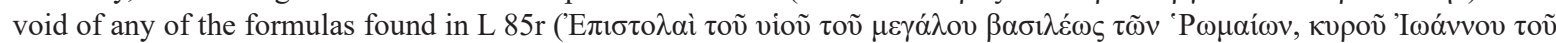


mitted in both manuscripts is extremely close, even in matters of accentuation and punctuation. The sequence of the selected letters in $\mathrm{V}$ follows exactly the sequence of the letters in $\mathrm{L}^{63}$. That the scribe changed exemplar between sections 7.9 and 7.10 after some time elapsed could also be inferred from the thinner pen, light-brown ink and different ductus he used, starting at line 8 of f. 108r (fig. 2). Section 7.10 was most probably copied directly from $\lambda$ (since $L$ is of a later date than $V$ ), from which the scribe of $\mathrm{V}$ himself excerpted the letters to Blemmydes and Akropolites. We can thus call the two parts of the Laskaris dossier, which reflect a different exemplar, $\mathrm{V}^{1}$ and $\mathrm{V}^{2}$ respectively.

All of the above suggests that $\mathrm{V}$ is a trustworthy copy with high textual value and very close to Theodore's wishes as they were expressed in his editorial project. The hypothetical history of the Laskaris dossier, along with the two distinct manuscripts transmitting the two larger collections of the emperor's letters ( $\mathrm{C}$ and $\mathrm{L}$ ), can be presented by the following diagram:

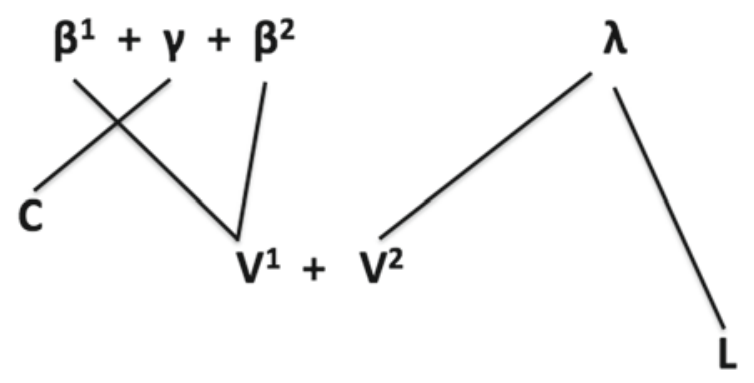

\section{THE SCRIBE OF V}

The foregoing analysis leads us to a discussion of the scribe and his work. As stated already, $\mathrm{V}$ is a small-sized book with almost minute and densely written letters on mediocre oriental paper. The palaeographical and codicological context indicates that $\mathrm{V}$ was not prepared for the book market but for the personal use of the scribe. The contents of the manuscript further suggest that the scribe was a professional teacher who prepared a selection of pedagogically useful and interesting texts, such as the grammatical treatises and the collections of letters, orations and progymnasmata of twelfth-century authors (Basilakes and Chrysoberges). It cannot be a coincidence that his selection of Laskaris' letters to Blemmydes and Akropolites in section 7.10, as well as his inclusion of a selection of Blemmydes' letters to Laskaris (section 8), focus on matters of education, learning and the relationship between pupils and teachers.

The learning of the scribe is confirmed by his marginal comments on f. $141 \mathrm{v}$ at the end of Manuel Holobolos' first encomium on the emperor Michael VIII Palaiologos, a work which probably dates to Christmas $1265^{64}$. The comments are written with a lighter ink in an extremely small and compressed ductus (fig. 3) ${ }^{65}$. In the concluding passage of the oration the speaker offers his laudatory wishes for the longevity and successful reign of the emperor and his son Andronikos ${ }^{66}$. The first

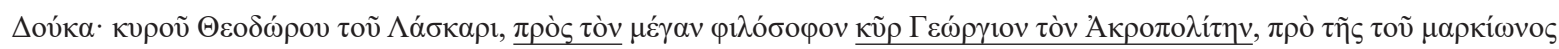
$\pi \rho \varepsilon \sigma \beta \varepsilon i ́ \alpha \varsigma)$.

${ }^{63}$ See above n. 35 for the numeration in FESTA's edition of the letters, which the scribe of V selected from the epistolary collection with pre-1254 letters.

${ }^{64}$ R. MACrides, The New Constantine and the New Constantinople - 1261? BMGS 4 (1978) 13-41, esp. 19 and 37 n. 137.

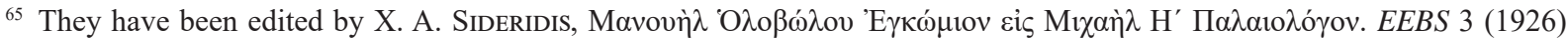
168-191, esp 170, who did not identify their textual origin and thought that the scribe was criticizing the author; M. TREU, Manuelis Holoboli Orationes I-II. Programm des Königlichen Victoria-Gymnasiums zu Potsdam. Potsdam 1906-1907, I, 49-50 did not include them in his edition.

66 Treu, Manuelis Holoboli Orationes I, 49.15-50.16. 


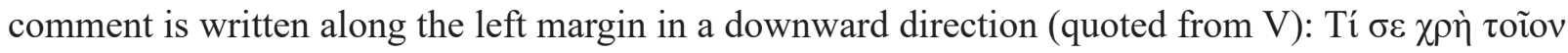

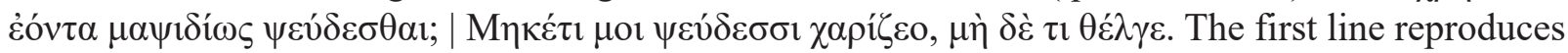

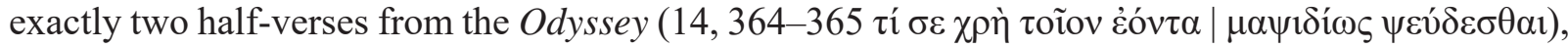
while the second line reproduces with variants another verse from the same book $(14,387 \mu \eta \dot{\tau \varepsilon} \tau$ í

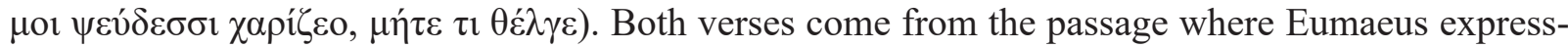
es his doubts to Odysseus disguised as an old stranger about his optimistic story of the fate of the king of Ithaca. The second comment is written in the lower margin across the whole page (quoted

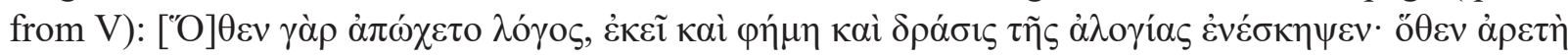

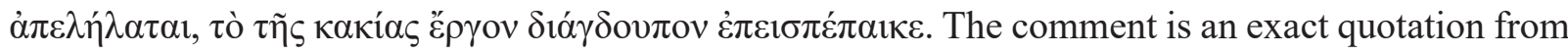
Blemmydes' Imperial Statue, where the corruption of leaders in the absence of virtue is described ${ }^{67}$. It is obvious that no average scribe would be able to write such comments and quote verbatim a difficult passage from a work by Blemmydes, which itself was difficult to find. Furthermore, the peculiar placement of the two comments on the margins of the page and the absence of any similar comments in the rest of the oration excludes the possibility that these passages were already present in the scribe's exemplar.

Who could have been the learned teacher of rhetoric who was active after the Byzantine restoration of Constantinople in 1261 and who was interested in imperial orations? We would like to propose that the scribe in question was the teacher and rhetorician Manuel Holobolos himself (d. ca. 1310-14) ${ }^{68}$. It has been suggested that a Byzantine author as scribe or commissioner sometimes incorporated his own works into a manuscript transmitting texts of another author or authors ${ }^{69}$. Something similar may have happened in V. The biography, high level of learning, educational career and literary interests of Manuel Holobolos all lend credence to this hypothesis. Holobolos was a young secretary to Michael VIII when he was punished with facial mutilation for expressing disquiet at the blinding of the child-emperor John IV Laskaris, the son of Theodore Laskaris, on Christmas Day 1261. For him to have been a young imperial secretary at the time, he ought to have received his education at an important school in the empire in Nicaea, which would explain his access to the official editions of Laskaris' writing. After his punishment, Holobolos was confined for four years to the monastery of John Prodromos in Constantinople known as the Petra monastery ${ }^{70}$. In 1265 Germanos III, the newly ordained patriarch (he was in office in 1265 and 1266), appealed to the emperor to pardon the learned Holobolos and to appoint him as a teacher in a state-funded Constantinopolitan school of higher learning ${ }^{71}$. Here Holobolos taught students rhetoric and logic for the next eight years ${ }^{72}$. He

${ }^{67}$ Blemmydes, Imperial Statue § 168 (ŠEvČENKo-Hunger 100).

${ }^{68}$ On the life and œuvre of Holobolos, see R. MaCridES, Holobolos, Manuel. ODB 2 (1991) 940; PLP no. 21047.

${ }^{69}$ S. PAPaionnnou, Fragile Literature: Byzantine Letter-Collections and the Case of Michael Psellos, in: La face cachée de la littérature byzantine: le texte en tant que message immédiat, ed. P. Odorico (Dossiers Byzantins 11). Paris 2012, 289-328, esp. 318-320, where he suggests that the famous Psellian manuscript Par. gr. 1182 (Diktyon 50786) could have been prepared at the behest of Eustathios of Thessalonike, because (among other reasons) of the inclusion of Eustathios' letters at the very end of the book. For similar examples from the early Palaiologan period see the Vat. gr. 112 (Diktyon 66743) written by George Galesiotes (I. Perez Martin, El Vaticanus gr. 112 y la evolución de la grafía de Jorge Galesiotes. Script 49 [1995] 42-59), or the Vat. gr. 2660 (Diktyon 69286) possibly written by Nikephoros Gregoras (S. LiLla, Eine neue (zum Teil eigenhändige) Handschrift des Nikephoros Gregoras (Vat. gr. 2660). JÖB 41 [1991] 277-282).

70 Pachymeres, I 3, 11 (Failler I, 259).

${ }^{71}$ Pachymeres, I 4, 14 (Failler II, 369-371). Pachymeres informs us that in 1265 Holobolos replaced the megas logothetes George Akropolites as a professor of logic. S. Mergiali-Falangas, L'école Saint-Paul de l'Orphelinat à Constantinople: bref aperçu sur son statut et son histoire. REB 49 (1991) 237-246, has shown on the basis of a close reading of Pachymeres that Acropolites' and Holobolos' school of higher learning was not located at the orphonatropheion of the church of Saint Paul, as it has been traditionally assumed.

${ }^{72}$ The duty of the twelfth-century "maistor of the rhetors" had been both to teach and practice rhetoric. That Holobolos taught logic emerges from Pachymeres' description (see the previous note) and from a poem by his student Thomas Gorianites dated 
held the teaching post of "rhetor of the rhetors" in the patriarchal administration, which marked the revival of the twelfth-century title of "maistor of the rhetors," and had the duty of delivering annual panegyrics of the emperor at Christmas, writing poems for the prokypsis ceremony at the court, and disseminating official news connected with the emperor ${ }^{73}$. Holobolos had the misfortune once again to fall out of the emperor's grace when Michael VIII began preparations for a union with the Latin church $^{74}$. In 1273 Holobolos was banished from the court on account of perceived opposition against the official unionist policy, even though he was highly useful for the emperor. Holobolos knew Latin and was the translator of two important works by Boethius on logic and other Latin texts ${ }^{75}$. He was at first exiled to the monastery of the Dormition of the Virgin in Nicaea and was later moved to the monastery tou Agrou in Kyzikos. Only after the death of Michael VIII in 1282 and the repudiation of the Union did Holobolos rejoin the court and resume his old responsibilities.

The chronologically latest texts in V were all authored by Manuel Holobolos. The Laskaris material is followed by Blemmydes' letters to Laskaris (section 8 of Hunger's description) and immediately thereafter by the works of Holobolos, which form a dossier of 4 quires with 24 folia and thus a distinct entity in V (sections 9-11 of Hunger's description). The heading of the first work copied (fols. $127 \mathrm{r}-135 \mathrm{v}$ ), a sermon written on behalf of Patriarch Germanos III, explicitly mentions Holobolos as its author ${ }^{76}$. In the margins the scribe systematically added notes explaining the rhetorical devices or offering alternative readings for various words (fig. 4) ${ }^{77}$. After the sermon the scribe copied a fifteen-syllable-verse poem for the court ceremony of prokypsis (fol. 135v), which is preceded

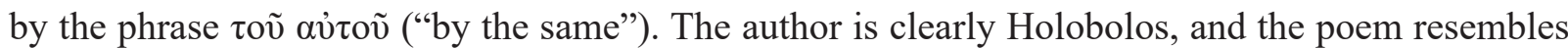
the nineteen prokypsis poems composed by him, that have been preserved in two Paris manuscripts ${ }^{78}$. The next work, the encomium on Michael VIII (fols. 136r-141v), does not have any heading indicat-

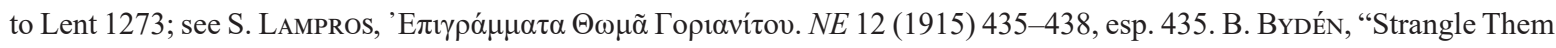
with These Meshes of Syllogisms!": Latin Philosophy in Greek Translations of the Thirteenth Century, in: Interaction and Isolation in Late Byzantine Culture, ed. J. O. Rosenqvist, Stockholm 2004, 133-157, esp. 138-139, suggests that Holobolos was appointed to teach the trivium, while the megas logothetes George Akropolites taught the quadrivium.

${ }^{73}$ On Holobolos as an official rhetorician see D. Angelov, Imperial Ideology 20, 38, 44-46. 67-70; IDEM, The Confession of Michael VIII Palaiologos and King David: On a Little Known Work by Manuel Holobolos. JÖB 55 (2006) 193-204.

74 Pachymeres I 5, 20 (Failler II, 501-505).

75 See BydÉn, "Strangle Them with These Meshes of Syllogisms", on Holobolos as a translator.

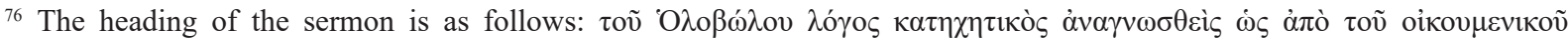

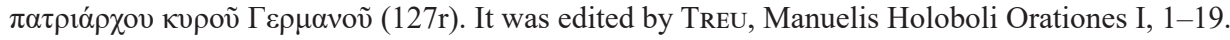

${ }^{77}$ All of these notes have been diligently edited by TREU (see previous note). In fig. 4 (f. 127r) one can see the scribe adding the name of the patriarch above the decorative band, while he also adds five explanatory notes on rhetorical techniques:

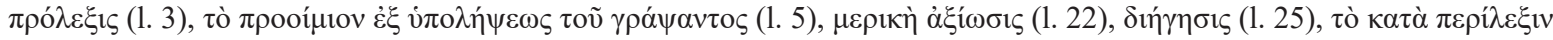
$\sigma \chi \tilde{\eta} \mu \alpha(1.30)$. It should be noted that some of these terms are quite rare. Thus, $\pi \rho{ }^{2} \lambda \varepsilon \xi 1 \varsigma$ is only attested in the lexicon of Hesychius as an explanation of $\pi \rho \rho_{\rho} \rho \eta \sigma ı \varsigma$ ("introductory statement"), while $\pi \varepsilon \rho i ́ \lambda \varepsilon \xi 1 \varsigma$ is explained in the Suda as $\pi \varepsilon \rho i ́ \varphi \rho \alpha \sigma 1 \varsigma$ ("periphrastic expansion").

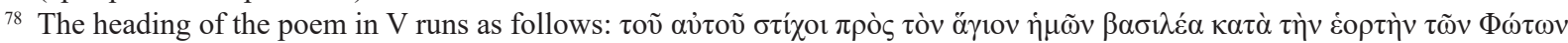

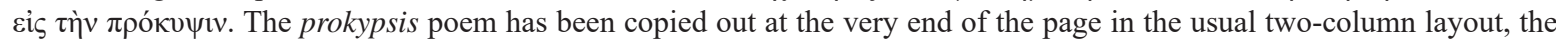
scribe using the same ductus but a lighter ink. The poem was edited by M. TreU, Manuel Holobolos. BZ 5 (1896) 538-559,

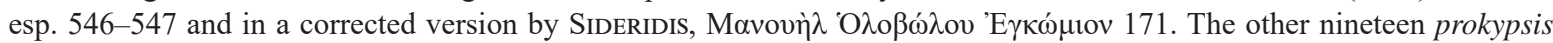
poems were edited from Par. gr. 39 (Diktyon 49600) and Par. gr. 400 (Diktyon 49973) by J. F. Boissonade, Anecdota Graeca. Vol. 5. Paris 1833, 159-182. On the historical references and suggested dates for six of the poems, see ANGELOv, Imperial Ideology 69, n. 151. Treu, Manuel Holobolos 547 suggested that the poem in V, the twentieth according to his count, was perhaps addressed to Andronikos II, which is clearly the case with the nineteenth and last one in Boissonade's edition (a suggestion followed by ANGELOV, Imperial Ideology 69 n. 152). However, there is nothing in the text of the poem to support this view. Rather, the codicological context suggests that Michael VIII was the addressee. A critical edition and further study of these poems is certainly needed. For the time being, see A. HeISENBERG, Aus der Geschichte und Literatur der Palaiologenzeit. Munich 1920, 127-130 (repr. in IDEM, Quellen und Studien zur spätbyzantinischen Geschichte. Gesammelte Arbeiten ausgewählt von H.-G. Beck. London 1973, no. I). 
ing author and subject (136r-141v). The encomium is the first of three long imperial orations, which Holobolos delivered at Christmas at the court during three successive years after his appointment as "rhetor of the rhetors," probably in 1265, 1266 and $1267^{79}$. The two texts that follow the encomium on Michael VIII in V are a draft, probably composed in 1265, of a letter by Michael VIII to Pope Clement IV $(141 \mathrm{v}-143 \mathrm{v})^{80}$, and an unedited Lenten homily on fasting $(143 \mathrm{v}-150 \mathrm{r})^{81}$. The two works are attributable to Holobolos' pen. In the left margin at the beginning of the letter to the pope (fol.

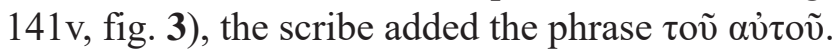

The scribal hand of Holobolos has not yet been identified. It has been suggested that the scribe Manuel of Par. Suppl. Gr. 642 (Diktyon 50223) (late 13th c.), who collaborated with George of Cyprus, might have been Holobolos. The identification is improbable not only because the surname Holobolos is missing. One would also expect Holobolos to identify himself with his distinctive title of rhetor (or that of protosynkellos at a later stage of his life), or use Maximos, his monastic name, during the periods of his disgrace (1261-1265 and 1273-1282) ${ }^{82}$. Two thirteenth-century manuscripts that transmit works of Holobolos can serve as a basis for a further palaeographical examination of the scribal hands found therein and in V. The first is the famous Oxon. Barocc. gr. 131 (Diktyon 47418) (ca. 1250-1280), written by eight scribes over a period of almost thirty years and containing a vast selection of texts from the middle of the eleventh to the late thirteenth century ${ }^{83}$. The Baroccianus transmits the second and third of Holobolos' encomia on Michael VIII in inverted order ${ }^{84}$. Oration 3 has been copied on fols. 236r-240v by scribe B, the manuscript's main scribe, while Oration 2 has been copied on fols. $244 \mathrm{r}-250 \mathrm{r}$ by scribe $\mathrm{C}^{85}$. Scribe B can almost certainly be identified with the scribe of Vat. gr. 106 (Diktyon 66737) (a. 1251) ${ }^{86}$. However, given that Holobolos' Oration 3 was delivered at the earliest at Christmas 1267, this part of the Baroccianus was copied after this date.

79 The laudatory speech to Michael VIII Palaiologos (preserved in V without a heading) was edited by Treu, Manuelis Holo-

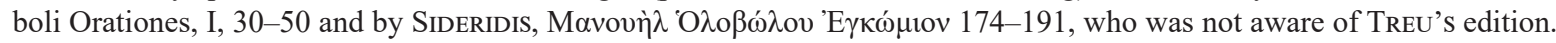
On the date and context of the three Christmas panegyrics by Holobolos, see MACrides, The New Constantine and the New Constantinople.

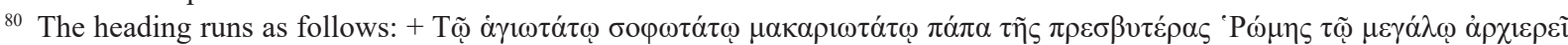

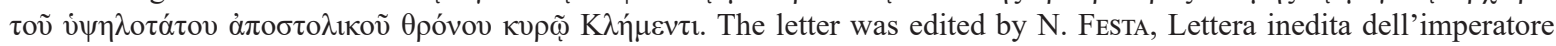
Michele VIII Paleologo al pontefice Clemente IV. Bessarione 4 (1899-1900) 42-57; for the attribution to Holobolos and the context, see N. FestA, Ancora la lettera di Michele Paleologo a Clemente IV. Bessarione 4 (1899-1900) 529-532; SIDERIDIS,

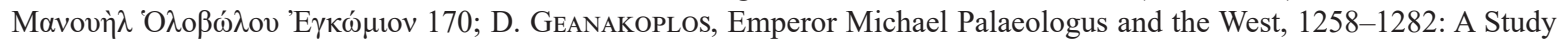
in Byzantine-Latin Relations. Cambridge, MA 1959, 200-202; BydéN, "Strangle Them with These Meshes of Syllogisms" 145 n. 60. The letter was re-edited and re-dated to ca. June 1265 by L. PIERALLI, La corrispondenza diplomatica dell'impero bizantino con le potenze estere nel tredicesimo secolo (1204-1282). Vatican City 2006, 167-183.

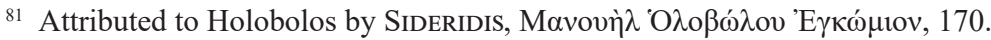

82 The identification of the scribe with Holobolos has been suggested, with a question mark, by D. HARLFINGER, Einige Aspekte der handschriftlichen Überlieferung des Physikkommentars des Simplikios, in: Simplicius, sa vie, son œuvre, sa survie. Actes du colloque international de Paris (28. Sept. - 1er Oct. 1985), ed. I. Hadot. Berlin 1987, 267-286, esp. 285

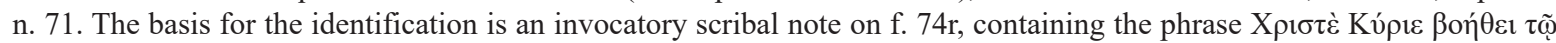

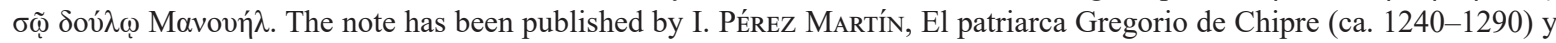
la transmisión de los textos clásicos en Bizancio. Madrid 1996, 22. The author (ibid. n. 16) doubts the identification with Holobolos. For the manuscript and its scribe see RGK IIA, 137 (no. 354) and IIC pl. 200. For the monastic name Maximos in the headings of Holobolos' Latin translations in Vat. gr. 207 (Diktyon 66838), see below n. 89.

${ }^{83}$ For a brief description with a first attempt at identification of the hands see N. WiLSON, Mediaeval Greek Bookhands: Examples Selected from Greek Manuscripts in Oxford Libraries. Cambridge, MA 1973, I, 29-30 and II, pl. 58-62; for a full description see IDEM, A Byzantine Miscellany: Ms. Barocci 131 Described. JÖB 27 (1978) 157-179. For a digital reproduction of the manuscript from the Bodleian Library, see http://digital.bodleian.ox.ac.uk/inquire/Discover/Search/ and ID 5d90cc41-2c6f-4e84-93bd-34696c448cd6 (accessed 08-07-2019).

${ }^{84}$ Edited by Treu, Orationes II in their proper sequence.

${ }^{85}$ For a specimen of B see Wilson, Mediaeval Greek Bookhands II, pl. 58 (f. 82r); for a specimen of C see ibid. pl. 60 (f. 244 r).

${ }^{86}$ A. TurYn, Codices Vaticani graeci saeculis xiii et xiv exarati annorumque notis instructi. Vatican City 1964, pl. 13. 
Scribe $\mathrm{C}$ who used a very dense script with a curly ductus, must have also been active after 1266, the earliest date of Holobolos' Oration 2. Neither of the two hands can be identified with the scribe of V, although the ductus of scribe $\mathrm{B}$ bears a general similarity to $\mathrm{V}$.

The second manuscript in question is the Vat. gr. 207, a miscellaneous codex thoughtfully put together between 1265 and 1268 by a learned man (interested in philosophy and employed at the patriarchate) and scribe in collaboration with a second scribe ${ }^{87}$. The manuscript is known for the list of its owner's books loaned by him to various relatives and colleagues at the patriarchate (f. VIIr), spanning a period of thirteen years (1268-1282) $)^{88}$. The owner (known as scribe 1) added the red headings in all of the manuscript, as well as a pinax of the volume's contents, also in red ink and a very florid style (f. 3r). A substantial part of the manuscript (section V, fols. 195r-278v) is devoted to Aristotle's Topics and Boethius' De topicis differentiis and De hypotheticis syllogismis, in a Greek translation by Manuel Holobolos, referred to by his monastic name Maximos, office and employment (fols. 237r-278v) ${ }^{89}$. These two texts have been copied by both scribes, whose different hands can be very clearly seen on f. 236r, where scribe 2 picks up on line 18 of the page. The headings written by scribe 1 make it obvious that he knew Holobolos personally. However, neither scribe of the Vat. gr. 207 can be identified with the scribe of V, nor can they be identified with Holobolos. The reason is to be found on $\mathrm{f}$. $273 \mathrm{r}$ of the Vaticanus, where scribe 1 began to write in an extremely dense script and with very small letters the text of Boethius' De hypotheticis syllogismis. Next to the beginning, in the right margin, the scribe has added a note to the readers warning them that the correct order of reading the two texts is first the De hypotheticis syllogismis and then the De topicis differentiis, but that he copied this way because it was only at a later point that he found the first text ${ }^{90}$. Furthermore, the hand of scribe 1 is not identical to scribes $\mathrm{B}$ or $\mathrm{C}$ of the Baroccianus.

More substantial research into the hands of late thirteenth-century scribes would be necessary to identify other manuscripts written by the scribe of $\mathrm{V}$ and test our hypothesis about the scribe being Manuel Holobolos. If our proposal is correct, the manuscript was written shortly after 1267 and probably before 1273, when Holobolos was exiled by Michael VIII for his anti-unionist stance. This proposal also explains how the scribe was able to find the manuscripts from which he copied his material, since as a professional teacher trained in the empire of Nicaea, he had access to important libraries in western Asia Minor and Constantinople. It also explains the comments on f. 141v, wherein the author criticizes in retrospect his own work in a highly learned way.

${ }^{87}$ For a splendid reconstruction of the whole process of production and the dating of the codex see P. CANART, A propos du Vaticanus Graecus 207. Illinois Classical Studies 7 (1982) 271-298 (repr. in IDEM, Études de paléographie et de codicologie. Reproduits avec la collaboration de M. L. Agati et M. D'Agostino. Tome II (StT 451). Vatican City 2008, 759-786. The manuscript is easily accessible in a good digital reproduction from the Vatican Library at https://digi.vatlib.it/view/MSS_Vat. lat.3195/0001 (accessed 14-10-2017).

${ }^{88}$ For the most recent edition and discussion see CANART, Vaticanus Graecus 207, 279-283.

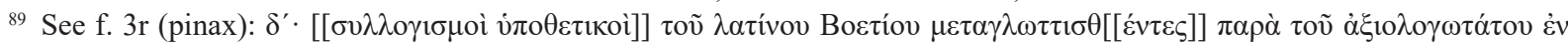

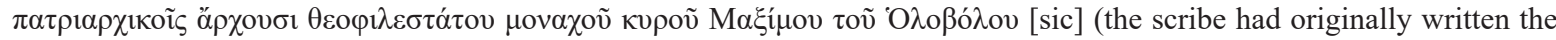

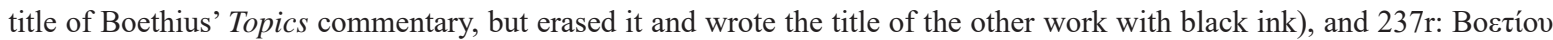

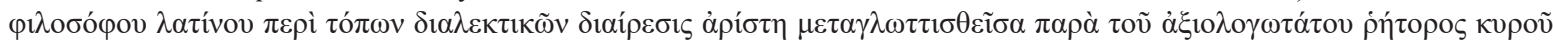

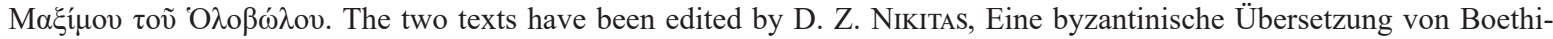
us' "De hypotheticis syllogismis" (Hypomnemata 69). Göttingen 1982 and IDEM, Boethius, De topicis differentiis אaì oi

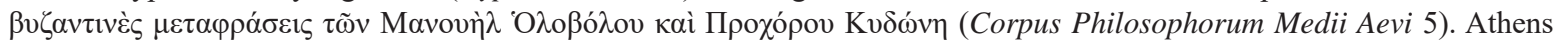
1990. For a broader appreciation in the context of the thirteenth century see E. A. FIsHER, Planoudes, Holobolos, and the Motivation for Translation. GRBS 43 (2003) 77-104 and EADEM, Manuel Holobolos and the Role of Bilinguals in Relations between the West and Byzantium, in: Knotenpunkt Byzanz: Wissensformen und kulturelle Wechselbeziehungen, ed. A. Speer - Ph. Steinkrüger (Miscellanea Medievalia 36). Berlin 2012, 210-222.

90 The note has been edited by CANART, Vaticanus graecus 207, 290 n. 20. 


\section{EDITORIAL MATTERS}

$\mathrm{V}$ employs a fairly consistent system of accentuation and punctuation, consonant with most manuscripts of the period 1150-1350 $0^{91}$. Thus, the scribe follows Byzantine practice in uniting adverbial

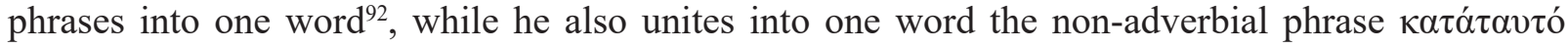
(1.23). The scribe treats $\delta \varepsilon$ as an enclitic when it follows an oxytone word ${ }^{93}$, otherwise he accentuates it $^{94}$. There is a similar fluctuation with $\tau \varepsilon \kappa \alpha i^{95}$. In most cases (ca. $70 \%$ ), the scribe keeps the gravis of an oxytone word before a comma or upper dot. He sometimes uses the double gravis, possibly for stress accentuation ${ }^{96}$. He once uses the trema to indicate vowel division (6.24 Өદïкñऽ). He uses iota subscriptum only once in all six essays $(6.12 \kappa \alpha \rho \pi о \nu \mu \varepsilon \dot{v} \omega)$. The scribe does use the upper dot plus comma sign as a question mark ${ }^{97}$, but he does not use commata to separate direct addresses ${ }^{98}$.

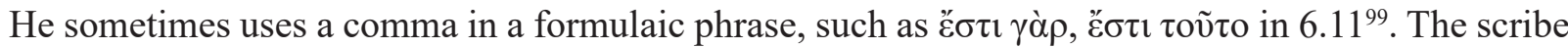
employs other devices to help the reading of the text. For example, he uses a dash to indicate words divided at line change ${ }^{100}$, but he does not do so in a few other instances ${ }^{101}$. Furthermore, he employs the hyphen to indicate compound words ${ }^{102}$, a characteristic practice of scribes from the thirteenth century onwards ${ }^{103}$. Generally, the scribe makes few errors, such as minor spelling mistakes ${ }^{104}$. Since most of these mistakes are found in Essay 6, this could be an indication of fatigue at the end of a long working period. In a number of cases the scribe corrected himself ${ }^{105}$.

In our edition we have followed the manuscript fairly closely, keeping the system of accentuation and punctuation almost intact, because this system supports a better reading and declaiming of the text, while also helping towards a better understanding of its meaning and stylistic aesthetics. However, we have regulated punctuation through the practice introduced by Roderich Reinsch in his edition of Psellos' Chronographia ${ }^{106}$. The debate about such practices is still ongo-

${ }^{91}$ On accentuation see J. NORET, L'accentuation byzantine: en quoi et pourquoi elle diffère de l'accentuation "savante" actuelle, parfois absurde, in: The Language of Byzantine Learned Literature, ed. M. Hinterberger (Studies on Byzantine History and Civilization). Turnhout 2014, 96-146; on punctuation see D. R. ReInsch, Stixis und Hören, in: Actes du VIe Colloque International de Paléographie Grecque (Drama, 21-27 septembre 2003), ed. B. Atsalos - N. Tsironi. Athens 2008, I, 259-269 (with substantial bibliography).

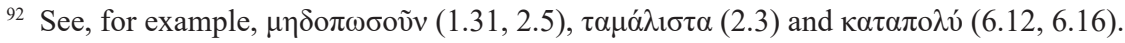

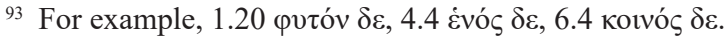

${ }^{94}$ For example, 1.23, 1.25 before a comma, 2.14, 4.5.

${ }_{95}$ See 2.6, 6.27.

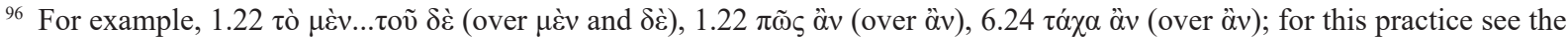
still useful study of M. ReIL, Zur Akzentuation griechischer Handschriften. BZ 19 (1910) 476-529, esp. 482-484, and now

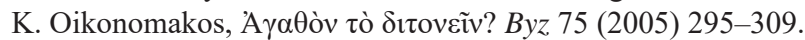

${ }^{97}$ See 2.12, 2.14-15, 5.7.

${ }_{98}$ See 1.32 and 2.2 .

99 In 2.20-21 he does not put a comma after $\gamma \grave{\alpha} \rho$ in the same phrase.

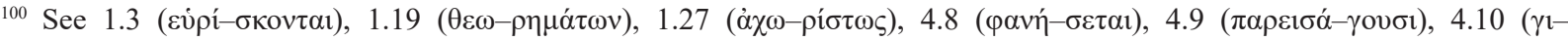

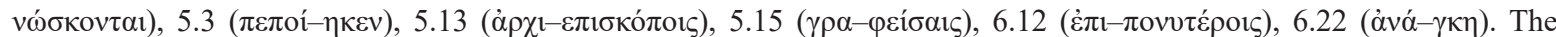
scribe follows the medieval practice as described by J. NORET, Les règles byzantines de la division en syllabes. Byz 77 (2007) 345-348.

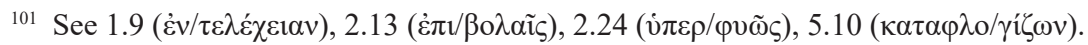

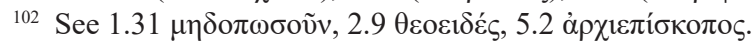

${ }^{103}$ Indicatively, one might mention the Barocc. 131, Laur. Conv. Sopr. 627, Par. gr. 857 (Diktyon 50444) (a. 1261), Par. gr. 400 (a. 1343/4).

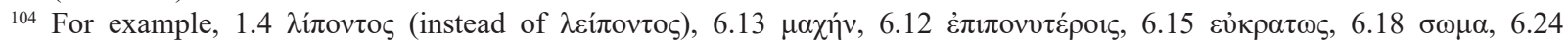

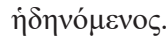

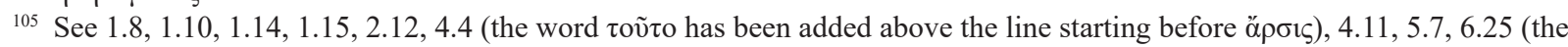
ő of ö $\tau$ has been corrected from something now illegible).

106 See, initially, D. R. ReInsch, What Should an Editor Do with a Text like the Chronographia of Michael Psellos, in: Ars Edendi. Lecture Series. Volume II, ed. A. Bucossi - E. Kihlman (Acta Universitatis Stockholmiensis. Studia Latina Stock- 
ing $^{107}$, with some editors choosing the conventional normative practice, while others print almost diplomatic editions ${ }^{108}$. It is certainly impossible to find one generally functional editorial practice for a variety of texts spanning the sixth to the fifteenth centuries, but an effort to approach such practice with a clear historical method is absolutely necessary.

Textual interferences have been kept to a minimum, for example, filling the minor lacunae resulting from small holes at the margins of the text column. The mistakes by the scribe are due to inner dictation ${ }^{109}$, misreading ${ }^{110}$ or possibly haste ${ }^{111}$. In a few instances we have retained a deviating Byzantine spelling, if it is attested in other contemporary or near contemporary tetxs ${ }^{112}$. If the scribe of $\mathrm{V}$ is Holobolos and the manuscript was written around 1270, then we have the opportunity to observe a well-educated, young teacher (approx. 25 years old) copying his material with a firm hand and in full control of his writing.

\section{THE TRANSLATION}

Translating the prose of Theodore Laskaris, with its unusual phraseology, allusive language, and wordplays, is a challenging task. The translation tries to convey as much as possible the spirit of the Greek text. We have chosen to render into English the Aristotelian concept of $\dot{\varepsilon} v \tau \varepsilon \lambda \varepsilon \dot{\chi} \chi \varepsilon 1 \alpha$ in Essay 1-which is usually translated (e.g., in the LSJ) as "full, complete reality" and "actuality" - as "full completeness" following the lead of Blemmydes, Laskaris' influential teacher. In Chapter IV of his Epitome of Physics, Blemmydes discusses the various meanings of the term. He unsurprisingly connects the concept with Aristotle, citing the latter's definition of motion (Physics 201a10-11) as "the actuality of what exists potentially, insofar as it exists potentially." Blemmydes explains that $\dot{\varepsilon} \nu \tau \varepsilon \lambda \dot{\varepsilon} \chi \varepsilon 1 \alpha$ could signify any of the following: a completed condition, the completeness of something, and a completed activity. An example of $\dot{\varepsilon} v \tau \varepsilon \lambda \varepsilon \dot{\varepsilon} \chi 1 \alpha$ is the human being developing out of an embryo, which appears in a fully completed form from the mother's womb at the time of birth ${ }^{113}$. A student of Aristotelian natural philosophy, Laskaris was attracted to this concept and made frequent use of $\dot{\varepsilon} v \tau \varepsilon \lambda \dot{\varepsilon} \chi \varepsilon 1 \alpha, \dot{\varepsilon} v \tau \varepsilon \lambda \varepsilon \chi \eta \dot{s}$ and $\dot{\varepsilon} v \tau \varepsilon \lambda \varepsilon \chi \tilde{\omega} \varsigma$ in non-philosophical contexts in his letters ${ }^{114}$.

holmiensia 58). Stockholm 2012, 131-154 with the objections of B. BYDÉN, Imprimatur? Unconventional Punctuation and Diacritics in Manuscripts of Medieval Greek Philosophical Works, in: Ibid. 155-172; see, finally, D. R. ReINSCH, Michaelis Pselli Chronographia (Millenium-Studien 51). Berlin-Boston 2014, I, xxxii-xxxvi.

107 See the stimulating papers gathered in: From Manuscript to Book: Proceedings of the International Workshop on Textual Criticism and Editorial Practice for Byzantine Texts (Vienna, 10-11 December 2009), ed. A. Giannouli - E. Schiffer (Veröffentlichungen zur Byzanzforschung 29). Vienna 2011, with the critical reviews by A. RIEHLE, BZ 105 (2012) 209-216 and C. M. Mazzucchi, Aevum 87 (2013) 613-614.

${ }^{108}$ See E. Paschos - Chr. Simelidis (eds.), Introduction to Astronomy by Theodore Metochites: Stoicheiosis Astronomike 1.5-30. New York-London-Singapore 2017, 30-34 for a discussion of the editor's normalizing choices; for the quasi diplomatic approach see RieHLe, Theodoros Xanthopulos 176-180. In both cases, the editors work with manuscripts and scribes absolutely contemporary to the authors and their texts.

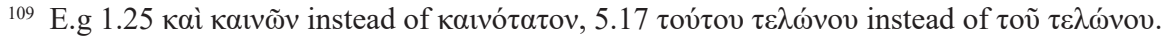

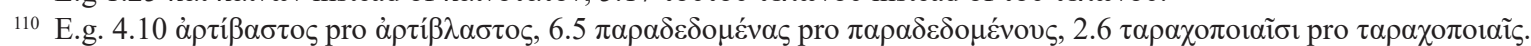

${ }^{111}$ In the heading of Essay 1 the scribe omitted the article before $\beta \alpha \sigma i \lambda \varepsilon i ́ \alpha$, against all other appearances of this formula in the Laskaris dossier.

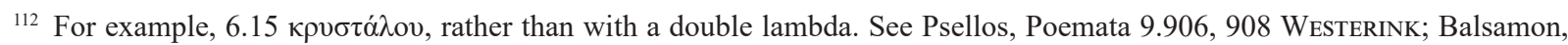

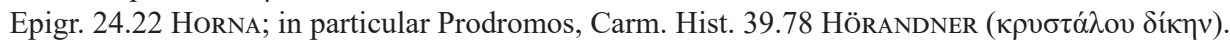

113 Blemmydes, Epitome of Physics $\S 4.1-2$ (PG 142, 1049A-1052A).

${ }^{114}$ For example, epp. 44.3, 63.3, 63.10, 109.14, 130.45, 133.9, 156.6, 184.24 (FEsTA 56, 92, 151, 182, 188, 218, 235). 


\section{DATE AND AUDIENCE}

Essay 1 dates, as its heading indicates, after the accession of Theodore Laskaris as sole ruler. His father, the senior emperor John III Vatatzes (1221-1254), passed away on 3 November 1254 and his only son Theodore, previously the junior coemperor, ascended the throne and was subsequently crowned in an ecclesiastical ceremony ${ }^{115}$. The chronology of the essay emerges not only from the heading, but is implicit in its discussion of the philosophical terminology with which Theodore Laskaris referred to his accession (see below the analysis of essay no. 1). The last essay (no. 6) dates to the second half of 1257 or 1258 - during the last year of the life of Laskaris who passed away on 16 August 1258 in Magnesia at the age of thirty-six ${ }^{116}$. The essay was written with hindsight of the author's experiences during the campaign he led in the Balkans against the Bulgarians (1255-56). Laskaris contemplates the causes for the ill-health of rulers, which he attributes to the physical hardships endured by them during military campaigns. The medical focus suggests that the author wrote the piece as he grappled to explain the deterioration of his own health. George Akropolites situates the onset of his fatal disease sometime in 1257 or $1258^{117}$. The thirteenth-century Jewish author Jacob ben Elia reports the duration of the illness as nine months, which would mean that its symptoms first manifested themselves in November $1257^{118}$. It may be added that in two of his seven post-1254 letters to Blemmydes copied in V, Laskaris openly speaks of his illness and describes its symptoms ${ }^{119}$.

The four intervening essays between the first and the sixth lack internal chronological indicators, although we can safely assume that the time of their composition falls between 1254 and 1258 . For one, the heading of Essay 1 may in fact pertain to all six essays. In addition, most of the Laskaris material in $\mathrm{V}$ that was part of the edited collection $\beta$, as reconstructed above, dates to the period of his sole rule. One further consideration for this dating can be adduced. The method of composition by dictation, which the author revealed to his readers in Essay 6 (see the discussion below), fits into his busy lifestyle in those years. It should be added that the satirical Essay 5 could not have been composed in 1255, because Theodore Laskaris was campaigning in the Balkans during the pre-Lenten period. The years 1256 and 1257 are the two likely dates for this essay.

The only clue regarding the intended audience is found at the end of Essay 1. The invocation "o wise men" (бофоì ö $v \delta \rho \varepsilon \varsigma)$ suggests his entourage of companions, all well-educated or with educational aspirations, who belonged to the generation born after the fall of Constantinople. Laskaris saw wisdom and philosophy ("the love of wisdom") as a special feature of his circle ${ }^{120}$. Some of its members, such as George Akropolites and Hagiotheodorites, were already highly educated, but there were men - especially young imperial secretaries and palace attendants - who Laskaris believed to

115 The accession is described in Akropolites’ History § 52-§ 53: HeISEnBERG, Georgii Acropolitae Opera I, 101-107. On the day of Vatatzes' death, see P. SchreIner, Die byzantinischen Kleinchroniken. Vol. 2. Vienna 1977, 195, 608 (no. 17-21).

116 The day of Laskaris' death is given by a chronological note in Vat. Palat. gr. 25 (153v) published by ScHreINER, Kleinchroniken II, 608 (no. 22). For Magnesia as the place of his obit, see Blemmydes, Partial Account II 80: ed. J. Munitiz, Nicephori Blemmydae autobiographia sive curriculum vitae necnon epistula universalior (CCSG 13). Turnhout 1984, 81.

117 History § 74: HeIsenberG, Georgii Acropolitae Opera I, 153.4-9. Akropolites reports the illness of Laskaris (drastic loss of weight, physical suffering, and inability of doctors to cure him) as developing after the political changes in Bulgaria reported in $\S 73$ (these took place in late 1256 and 1257) and after the embassy sent by the new Bulgarian ruler Constantine Tikh to Laskaris, which resulted in the marriage of the latter's eldest daughter Irene to the former. Nikephoros Gregoras follows Akropolites by noting that Laskaris fell ill when he was in the thirty-sixth year of his life; see L. SCHOPEN, Nicephori Gregorae Byzantina historia, vol. 1. Bonn 1829, 61.18-62.2.

118 See the letter written in about 1270 in Valencia by Rabbi Jacob ben Elia of Carcassonne in S. Bowman, The Jews of Byzantium, 1204-1453. Tuscaloosa, AL, 1985, 229. See also J. MANN, Une source de l'histoire juive au XIIIe siècle: la lettre polémique de Jacob b. Elie à Pablo Christiani. Revue des études juives 82 (1926) 363-377.

119 Ep. 48 (Festa 64-66); see also ep. 45.57-70 (Festa 62).

${ }^{120}$ Ep. 49 (FESTA 67-71). 
be in need of further training. Thus, he addressed a Trinitarian treatise to the secretary John Phaix and the koubouklarios (chamberlain) Constantine ${ }^{121}$. His childhood friend and political protégé George Mouzalon, the power behind the throne during the last two years of his life, was the recipient of his disquisition on friendship and politics (Response to Mouzalon), and the philosophical treatise Explanation of the World. The three overtly philosophical essays (1,3 and 6) may have had similar instructional agenda. Essay 5 seems also to have been addressed to his companions, although its agenda is different. It satirizes the archbishop of Ephesos and resembles the "clergy jokes" that circulated among young laymen in his entourage ${ }^{122}$. The author calls the audience of these jokes simply

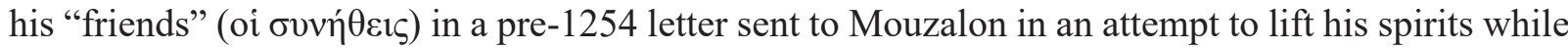
the latter was recovering from an illness ${ }^{123}$. The intended readership of the essays, thus, was likely to have consisted of the usual audience of Laskaris' philosophical and satirical works - educated courtiers whom he promoted to high positions during his brief reign. It should be added that Akropolites is unlikely to have been among the addressees of the six essays, for he was not near Laskaris in the last two years of his life, because he was appointed to a high position in the Balkans in the second half of 1256 and fell into Epirote captivity in $1257^{124}$.

\section{GENRE, STRUCTURE AND LANGUAGE}

The six essays of Theodore Laskaris edited here resemble to a certain extent the twelve 'E $\pi 1 \tau 0 \mu \alpha i$ $\eta \dagger \theta$ ikai (Moral Pieces) on religious and philosophical topics, which he wrote while mourning the death of his wife Elena Asenina in $1252^{125}$. They also resemble, to a lesser extent, the seventeen

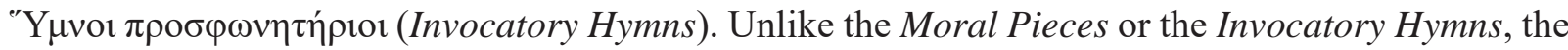
six essays do not have a unifying title to characterize them, nor do they appear, initially at least, to form a literary unit in the strict sense of the term, since their topics range from natural and political philosophy to self-reflection and satire.

The brief texts have a contemplative character and are defined in their headings as $\gamma v \omega \mu \eta(1,6)$, $\theta \dot{\varepsilon} \sigma ı \varsigma(4,5)$ and $\lambda \tilde{\eta} \mu \mu \alpha(3)$. While the first two terms ("maxim", "thesis") are derived from progymnasmatic school practice ${ }^{126}$, the third ("proposition, premise") draws on mathematical and philosophical language ${ }^{127}$. The exception to this type of terminological description is Essay 2, which in its

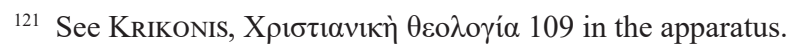

122 See below nn. 123, 166.

${ }^{123}$ See, for example, Ep. 158 (FESTA 218-219) addressed to Mouzalon. The letter describes how one morning the author received his friends after breakfast, as was his custom, and a member of the group brought up the subject of the bishop Monikos (Monoikos). All burst into laughter-Mouzalon was also invited to do so from afar-when they remembered the comic physique, speech and musical abilities of the bishop.

${ }^{124} \mathrm{On}$ the Balkan assignment of Akropolites as praitor and the events that led to his captivity, see History $\S 67-\S 68, \S 70-\S 72$ (HeISENBERG, Georgii Acropolitae Opera I, 139-143, 144-151); MACRIDES, George Akropolites 12.

${ }^{125}$ For an edition with introduction, translation and notes see Angelov, Moral Pieces.

${ }^{126}$ Hermog. Prog. 4 and 11 (ed. M. Patillon, Corpus Rheotricum, Anonyme, Préambule à la rhétorique - Aphthonios, Progymnasmata - Pseudo-Hermogène, Progymnasmata. Paris 2008, 187-189, 203-205) and Aphth. Prog. 4 and 13 (ibid., 117-120, 152-157); for an English translation with notes see G. A. Kennedy, Progymnasmata: Greek Textbooks on Prose Composition and Rhetoric. Leiden-Boston 2003, 77-78 and 87-88 (Hermogenes), 99-101 and 120-124 (Aphthonios). On the meaning of $\gamma v \omega ́ \mu \eta$ in Aristotle's Rhetoric and the adjective $\gamma v \omega \mu$ кós, see B. BYDÉn, The Nature and Purpose of the Semeioseis gnomikai: The Antithesis of Philosophy and Rhetoric, in: K. HuLt, Theodore Metochites on Ancient Authors and Philosophy: Semeioseis gnomikai 1-26 \& 71. Gothenburg 2002, 245-288, esp. 255-258.

${ }^{127}$ Archim. DeConoid. I 159.3 (et passim); Gal. HippPlat. II 3.8.3; DiogLaert. VIII 76.9; SextEmp. AdvMathem. VIII 225.10 (et

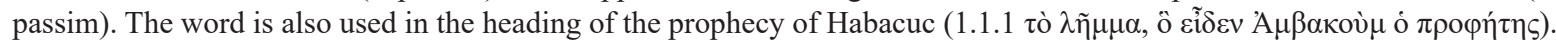

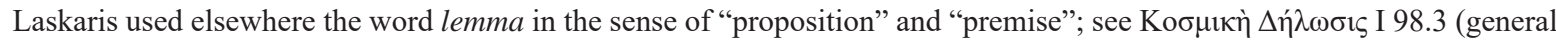
preface); epp. 202.59 (Festa 250), 212.10 (Festa 264). 


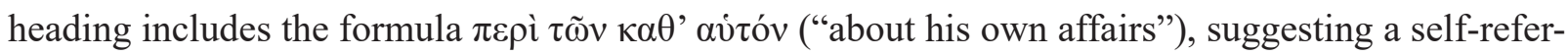
ential and autobiographic perspective ${ }^{128}$. Essay 1 is characterized in the text as lemmation (1.31 દi kaì

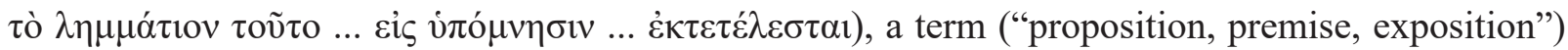
used quite often in mathematical, philosophical and theological treatises ${ }^{129}$. In Essay 6 the text is

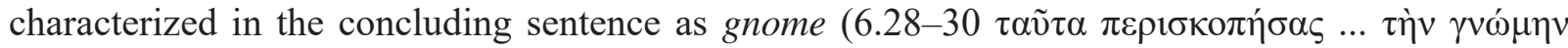
$\dot{\varepsilon} \xi \dot{\varepsilon} \theta \varepsilon \tau$ ), the same term as in the heading. Finally, it is possible that a reference to the essays as whole

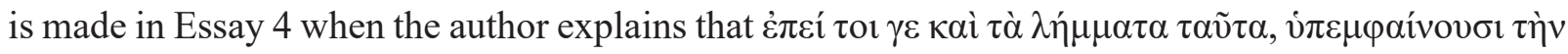
$\dot{\alpha} \lambda \hat{\eta} \theta \varepsilon i \alpha v$ ("because these propositions here present the truth").

Five of the six essays start with a "proposition" that is then expounded. However, the propositions are the author's own thoughts and not maxims of ancient sages, as was the usual practice in the schools. These propositions are the following:

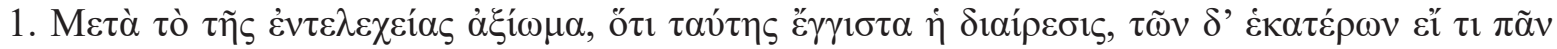
$\dot{\varepsilon} \nu \tau \varepsilon \lambda \varepsilon^{\prime} \zeta$.

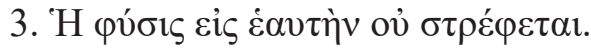

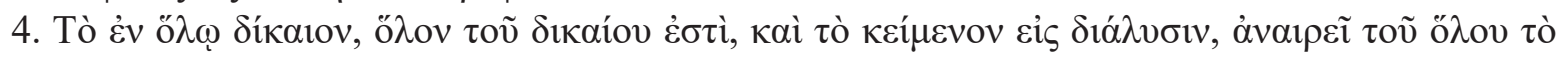

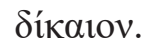

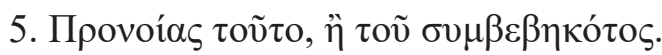

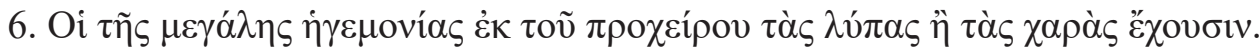

While Essays 1, 3, 4 and 6 treat serious topics, Essay 5 is quite special in that this text is, in fact, a satirical invective composed in the form of a syllogistic exposition, thus displaying a clear generic hybridity - in other words, an amalgamation of two different types of genre and discourse ${ }^{130}$. Forming a loose collection of didactic notes, the texts use devices from various traditions such as the progymnasmatic exercise, the philosophical maxim, the monastic apophthegmata and even katanyktic hymnography. The texts are very loosely structured and follow an associative logic in the exposition of the topics, giving the impression of being entries in a diary rather than fully developed essays in the modern sense of the term. Their style is at times close to the Moral Pieces, at times close to the Explanation of the World, at times close to Laskaris' letters, especially the humorous ones. As in many of his other works, here also the main intellectual framework is delineated by Laskaris' interest in mathematics and geometry, natural and political philosophy, but also hymnography.

The six essays display a dense and opaque language. Notable are the rare word $\alpha \rho \tau i \beta \lambda \alpha \sigma \tau o \varsigma$ (4.10) and the even rarer noun ó $v \tau \imath \pi \alpha ́ \lambda \alpha ı$ ( $(6.6)$, which is known solely from the History of Niketas

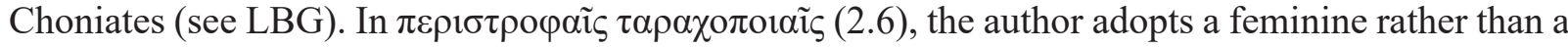
masculine/neuter ending in a composite adjective modifying a feminine word, a practice he follows

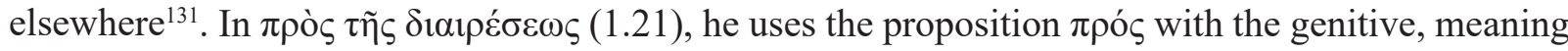
"from," as he does elsewhere ${ }^{132}$.

${ }^{128}$ On this type of title and its potential generic connotations see M. HINTERBERGER, Autobiographische Traditionen in Byzanz (WBS 22). Vienna 1999, 97-116.

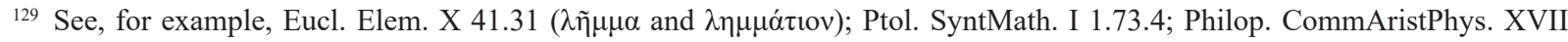
661.16; CyrAlex. CommProphMin. I 639.17 or II 216.7.

130 On hybridity and amalgamation in Byzantine literature see, indicatively, S. Constantinou, Generic Hybrids: The "Life" of Synkletike and the "Life" of Theodora of Arta. JÖB 56 (2006) 113-133 and P. A. AGAPITOs, New Genres in the Twelfth Century: The schedourgia of Theodore Prodromos. MEG 15 (2015) 1-41.

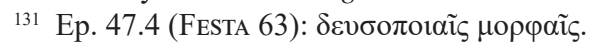

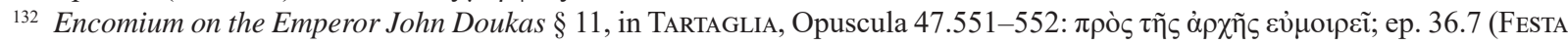

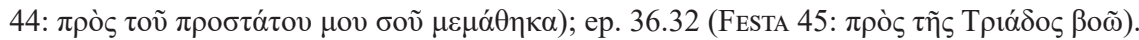




\section{ORALITY, FLUIDITY AND COMPOSITION BY DICTATION}

The concluding sentence of Essay 6 (28-30) contains a clue signalling both orality and tight authorial control: "After having examined these things with a far-seeing eye and with the sharpness of thought and the judgement of knowledge, he expounded the maxim, although he knows more than what has been said." This comment seems to suggest that the author dictated his composition to a secretary, such as was his companion and eventually high imperial official Hagiotheodorites, whom Laskaris describes in a pre-1254 letter to Blemmydes as "the expert connoisseur of my tongue, of my heart and of the thoughts of my mind, and an admirable secretary." 133 The phrase "with a far-seeing eye"

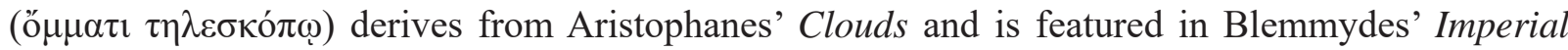
Statue ${ }^{134}$. The rare quotation with its elevated vocabulary cannot have been added by a recording secretary, but belongs to the author himself.

Oral composition obviously requires improvisation, and improvisation presupposes the existence of a certain stock of phrasal formulas. We do not find such formulas in Laskaris' texts, but we can detect a certain stereotyped use of syntactical structures that are based on rhetorical tropes, such as

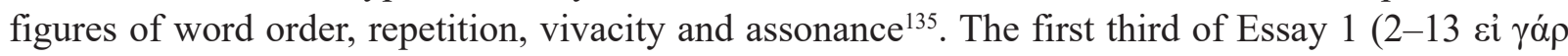
$\tau 01 . . . \kappa \alpha i ̀ ~ u ̛ \pi \alpha \rho \xi 1 \varsigma)$ is a very good example of this "poetical," extremely rhythmical yet highly loose prose with its long catalogue of very short cola (5-9) framed by complex sentences (2-5 and 9-13), which are themselves structured in a very fluid manner. Similar is a most difficult passage from Essay 4 (lines 5-9), where we can see the extremely pronounced associative movement of thought and

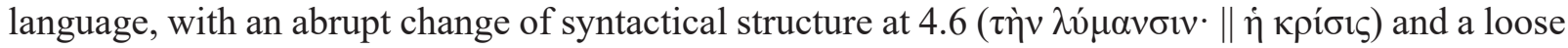

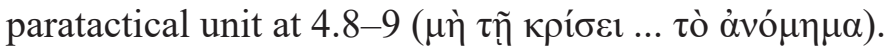

Laskaris often wrote in a manner that looks as if improvised, and the texts closest to this style of the six essays are the twelve Moral Pieces of 1252. Otherwise, however, his style was very carefully prepared, giving only the appearance of improvisation as, for example, a long passage in the Response to Mouzalon (composed between 1250 and 1254), clearly shows ${ }^{136}$. The author was admired for his capacity for swift and powerful improvised composition as a comment of George Pachymeres suggests: "He was a highly learned man to the greatest degree, and he showed himself beneficent towards all learned men, but he no less practiced himself also literary culture, possessing the power of writing more from nature than education, so that he could compose a lot with great fluency should he start." ${ }^{137}$ Pachymeres offers an anecdote to support his claim, in which the readers see the emperor

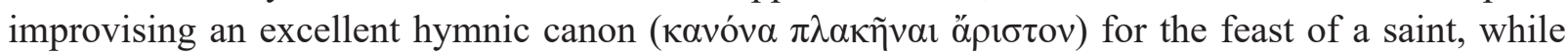

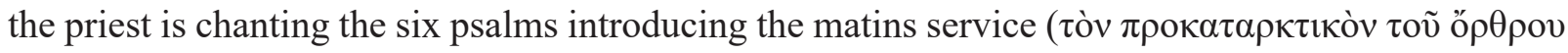
$\dot{\varepsilon} \xi \alpha \dot{\alpha} \alpha \lambda \mu \mathrm{Nov})^{138}$. A few such canons by Laskaris have survived, one of which is a hymn of salutation to

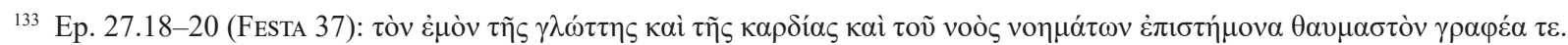

134 See above $n .12$ to the translation.

${ }^{135}$ For a detailed analysis of such tropes in a poem see P. A. AgAPItos, Public and Private Death in Psellos: Maria Skleraina and Styliane Psellaina. BZ 101 (2008) 555-607, esp. 565-568.

136 Response to Mouzalon § 5-6 (TARTAGLia, Opuscula 127.169-133.316). Laskaris describes to his close companion and future "prime minister" the character traits of a man who wishes to be a friend out of advantage $(\S 5)$ and out of pleasure (§ 6). The first section appears as an improvised "stream-of-consciousness" composition but is not, while the second section appears as a rhetoricized list of sentences describing the pleasures of court life. For an analysis of this passage see A. ANDREOU - P. A. Agapitos, Of Masters and Servants: Hybrid Power in Theodore Laskaris' Response to Mouzalon and in the Tale of Livistros and Rodamne. Interfaces-A Journal of Medieval European Literatures 6 (2019) - forthcoming.

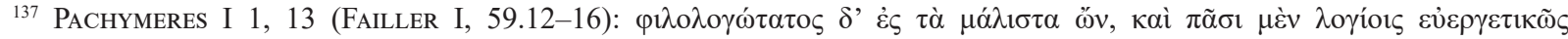

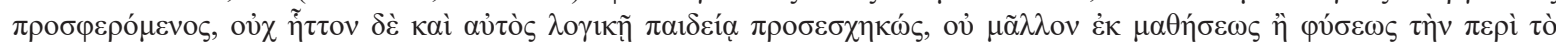

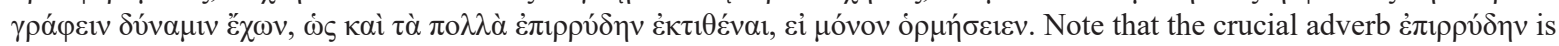
a hapax legomenon of Pachymeres, not documented in the LBG.

138 Ibid. (FAILlER I, 59.16-61.2). 


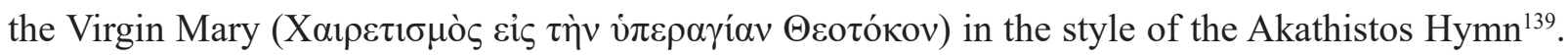
As Antonia Giannouli has shown, the hymn is based on a prose encomium of Laskaris in honour of the Akathistos Feast ${ }^{140}$. Here we have the opportunity to see how an extremely rhythmical prose text - simultaneously ecstatic and fully controlled - is transformed into a hymn of similar ecstatic style and yet bound in the form of the hymn's metrical model. To these two texts one can easily compare

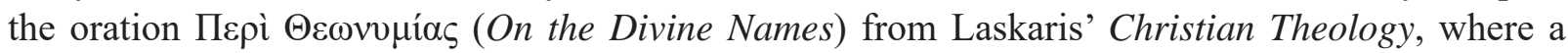
series of over seven hundred attributes of God are collected and catalogued in a superbly rhythmical and mystical manner ${ }^{141}$.

However, this power of a performative, ritualistic and ecstatic way of writing is not what we find in the six essays. Their style is neither performative nor ritualistic, and certainly not ecstatic. The continuous syntactic shifts, internalized rhythmical organization and obscure language suggest a person dictating in forced haste his thoughts in order to communicate them to himself or to a specific audience as advice and admonition for political or philosophical matters. In this sense, these six short notes are the only instance where we have the personal voice of an emperor and author speaking $\varepsilon i \varsigma$

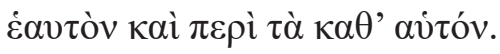

\section{BRIEF ANALYSIS OF THE ESSAYS}

\section{Essay 1: "Full completeness"}

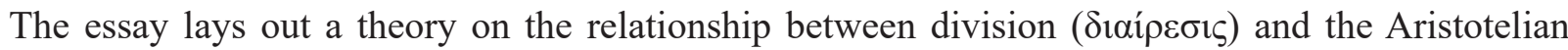
concept of $\dot{\varepsilon} v \varepsilon \varepsilon \lambda \dot{\varepsilon} \chi \varepsilon 1 \alpha$ ("full completeness"). It is notable that the author used the phrase "full completeness of imperial rule" ( $\left.\dot{\varepsilon} v \tau \varepsilon \lambda \varepsilon \dot{\chi \varepsilon \varepsilon 1 \alpha} \tau \tilde{\eta} \varsigma \beta \alpha \sigma i \lambda \varepsilon i \alpha_{\varsigma}\right)$ to refer to his accession as sole emperor. Entelecheia commonly features in headings of texts in collections prepared during Laskaris' four-year reign, such as Christian Theology and collection $\beta$ as reconstructed above ${ }^{142}$. The essay confirms Theodore's interest in the concept of entelecheia and - what is more significant - demonstrates that its presence in so many headings was a conscious choice of the author, for he interpreted his accession through the prism of this Aristotelian term. The usage of the phrase strongly suggests that during the last years of his life he supervised the copying of his works in edited collections.

The proposition of the essay takes its subject from its heading. The author gives a hint in the opening sentence that he has already received the axioma of entelecheia ("after the dignity of full completeness"). The meaning of the puzzling expression becomes clear when one considers that $\dot{\alpha} \xi i \omega \mu \alpha$ can refer to the dignity of the emperor. The proposition is that division is close to full completeness as well as to dignity itself. Division generates new entities in a completed form and bestows on them dignity which, mutatis mutandis, is absent from conjoined things. A range of abstract examples is given in support of this thesis. The inspiration for the proposition is never discussed, but can be gleaned by reading between the lines. The death of his father and Theodore's accession as sole emperor was itself an act of division, because it put an end to the joint rule of the senior and junior emperor, and brought about the "full completeness" of his rule.

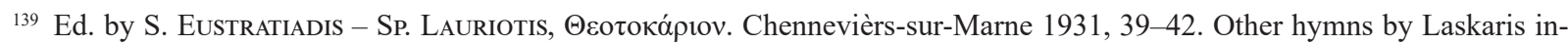
clude his Great Supplicatory Canon to the Virgin ( $\mu \varepsilon ́ \gamma \alpha \varsigma \pi \alpha \rho \alpha \kappa \lambda \eta \tau 1 \kappa o ̀ \varsigma ~ \kappa \alpha v \omega ́ v), ~ P G ~ 140,771-780$, and another canon to the

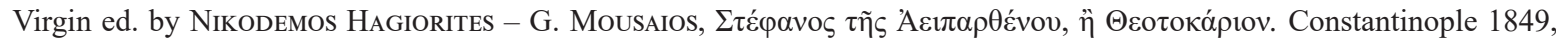
93-96.

140 A. Giannouli, Eine Rede auf das Akathistos-Fest und Theodoros II. Dukas Laskaris. JÖB 51 (2001) 259-283, esp. $264-266$.

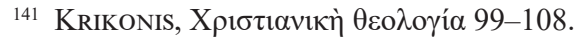

${ }_{142}$ On the headings of the works in the two collections, see above pp. 49-52, 54-56 and nn. 49, 56-57.
} 


\section{Essay 2: The pleasures of courtly life renounced}

This is the most explicitly autobiographic essay of the collection, with no proposition to argue about, but with the author's gaze focused on himself. The essay's main theme is the need of the ruler to control his fleshly desires and to elevate himself and his soul through his ruling intellect (i $\gamma \varepsilon \mu \omega ́ v)$

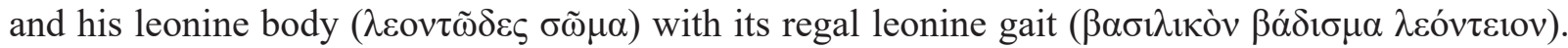
There is a similarity here with Essay 6 which also focuses on the emperor's body, albeit from a very different angle (see the analysis below).

The direct addressee of this essay is the emperor's "belly-enslaved flesh" ( $\gamma \alpha \sigma \tau \rho i ́ \delta o v \lambda o \varsigma \sigma \alpha ́ \rho \xi)$ that stirs itself in arrogant rebellion and ultimately leads the ruler to the worst ${ }^{143}$. The ally, or even weapon, of the flesh is pleasure (i்oví). In the essay, Theodore refers to three types of pleasure: (i)

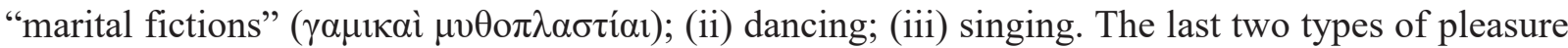

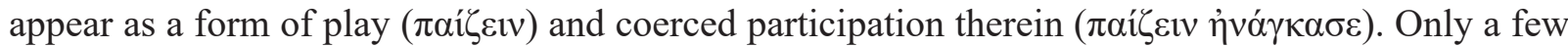
years earlier, Laskaris as crown prince had described such activities in his Response to Mouzalon. In this text, pleasures handed out by the emperor at the "imperial court" ( $\beta \alpha \sigma i ́ \lambda \varepsilon 1 \alpha \imath \alpha v i \lambda \alpha i)$ saturate the person desirous of money, banquets, luxurious clothing, songs, hunting, riding, or sports ${ }^{144}$. That Theodore enjoyed these aspects of courtly life is vividly described by Pachymeres in a moralizing anecdote in his History, according to which Vatatzes met his son out in the countryside as the latter was returning from a hunt dressed in luxurious clothes. The emperor scolded the young prince for foolishly spending the "blood of the Rhomaioi" in such pastimes ${ }^{145}$. In another essay titled Encomium on Spring and on a Charming Man, also written before 1254, Laskaris speaks of an inner disposition towards melancholy. "Conditions of gloom, as if by a winterstorm, and thoughts disturb

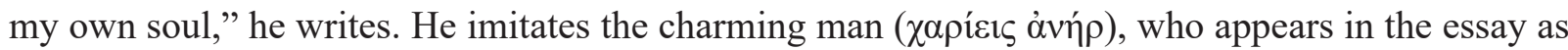
the perfect courtier, in order himself to feel like spring, always pleasant and smiling, always ready to be friendly to other people, although this is not his "true" character ${ }^{146}$. What Laskaris expresses in Essay 2, now that he is the sole ruler, is a rejection of this courtly life in favour of imperial austerity, which has elevated him to "magnificence" ( $\mu \varepsilon \gamma \alpha \lambda \circ \pi \rho \varepsilon \dot{\pi} \varepsilon 1 \alpha)$ and "beautified nobly and marvellously

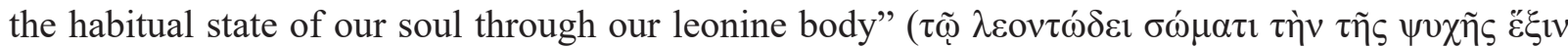

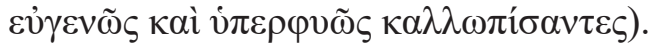

A most intriguing issue is the "marital fictions" to which Laskaris refers. The whole sentence reads: "And in marital fictions you invent for me phantoms of truth, confusing my faculty of imagination and presenting me with shadows instead of the actual being, while divesting grace of its prominence through a small and fleeting pleasure" (9-12). Does Laskaris hint here at his own marriage with Elena as a "fiction"? Or does he refer to the reading of love stories as "fictions"? The second option seems more probable, because Laskaris expressed most passionately his love for his deceased wife in the Moral Pieces ${ }^{147}$. With Elena he not only had a very good marriage but also six children, of

${ }^{143}$ The rare noun $\gamma \alpha \sigma \tau \rho i \delta$ ov $\lambda$ o $\varsigma$ was used as an adjective by the Church Fathers, especially to characterize "the race of eunuchs" with abusive terms (see, for example, Basil of Caesarea, ep. 115.22 or Palladius, Dial. 92.12). Here, the negative characterization is transferred to the flesh, i.e. the body in its carnal manifestation. The image of the belly as an independent force of greed is already present in the Odyssey (see 17.228 and 18.1-4) and plays an important role in the early ecclesiastical authors (Clemens of Alexandria, Basil, Gregory of Nazianzus, Evagrius Ponticus). We find the motif fully developed as a satirical trope in Psellos' verse invective Against the Sabbaitan Monk (Poemata 21.17-18 and passim) and Prodromos' novel Rhodanthe and Dosikles (4.122-188).

144 Response to Mouzalon § 6 (TARTaGlia, Opuscula 130.251-132.296).

${ }^{145}$ PaChymeres I 1,14 (Failler I, 61-63). In his Encomium on the Emperor John Doukas § 11 (Tartaglia, Opuscula 46.53647.558), he praises his father for having rejected such courtly pleasures in favour of a more austere way of life.

146 Encomium on Spring § 7 (TARTAGLia, Opuscula 151.252-152.260).

${ }^{147}$ Moral Pieces § 12 (Angelov, Moral Pieces 267.483-268.495). 
which their son was to become his successor. Furthermore, Laskaris refused, against the advice of his counsellors, to remarry after the death of Elena and voiced dramatically his preference for the austere life of a philosopher ${ }^{148}$. It is difficult to see that such a marriage was "a small and fleeting pleasure"

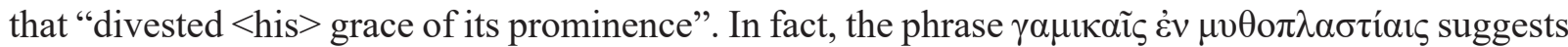
an objectification of this image; it is "in" ( $\dot{\varepsilon} v)$ these fictions that pleasure "invents for [him] phantoms of truth" which confuse the intellect. Furthermore, love stories are "marital fictions" because they end in marriage. Needless to say, the often mentioned codex $C$ (see above p. 52) transmits, along with Laskaris' letters to Mouzalon and other Nicaean texts, four of the five surviving ancient novels (Longos, Achilles Tatios, Chariton, and Xenophon) ${ }^{149}$. It might not be a coincidence that in Chariton's novel, the marriage of the protagonist couple is presented as a public lawful act (I 1.11, III 1.6, III 2.8), while in the author's narratorial intervention that leads his story to its happy conclusion, the

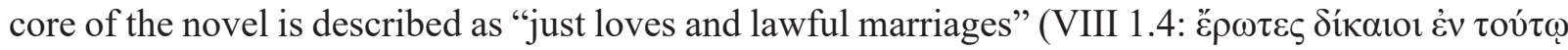

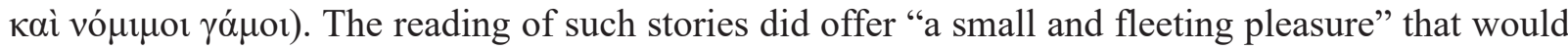
fit quite well into the pleasures of courtly life, which Theodore now rejects.

\section{Essay 3: Nature and empiricism}

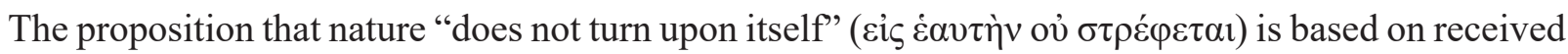
philosophical tradition. According to Proclus in his Elements of Theology ( $\$ 15-17$ ), a material body cannot revert on itself (the verb used is غ̇ं $1 \sigma \tau \rho \dot{\varepsilon} \varphi \varepsilon \tau \alpha 1)$ by reason of its nature, but that which is incorporeal and entirely separate from the body is capable of doing so. Everything that is self-motive is capable of returning to itself. Blemmydes adapted the same idea to the Christian context in the chapter devoted to nature in his encyclopedic Epitome of Physics. Here Blemmydes compared God and nature with regard to their work of creation. He supplied Aristotle's definition of nature as "the principle of motion and rest" (Physics 253b8-9) with the qualification that "nature moves by being moved" by God, a qualification that rests on the criticism of Aristotle for denying the theory of Creation ${ }^{150}$. Blemmydes went on to contrast the supreme creative power of God to the secondary

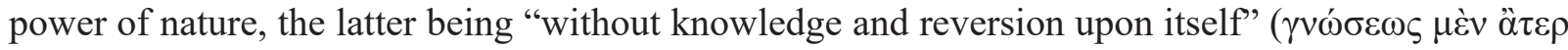

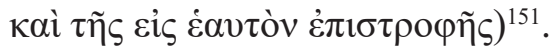

The same idea forms the proposition of the essay. Notably, Laskaris avoided any reference to theology or the scriptures and supported the proposition through an argument based on reductio ad absurdum. If nature "turned upon itself," then it would either grind to a halt (in accordance with Aristotelian theory of motion in the sublunary sphere) or lose its characteristics. The reasoning betrays a conception of nature as a powerful force in continual and uninterrupted action, a view found elsewhere in his philosophical thought. According to his treatise Natural Communion, nature has generative and motive power: everything comes from or revolves around nature in a way similar to the water cycle of rainfall and vaporization. Nature is the beginning and the midpoint of the four

\footnotetext{
${ }^{148}$ See his short piece against remarriage, where he opts for marrying "philosophy" (TARTAGLIA, Opuscula 110-117); first edition with Italian translation by IDEM, Una apologia inedita di Teodoro II Duca Lascari. Bolletino dei Classici, ser. III, 12 (1991) 69-82.

149 The four texts are preceded by a poem written by the school teacher Skoutariotes, wherein he dedicated the four novels to the young emperor Alexios II Komnenos (1180-1183); see G. CAVALLO, Il libro come oggetto d'uso nel mondo bizantino. JÖB 31.2 (1982) 395-427, esp. 414-415.

${ }^{150}$ This strand of Byzantine criticism of Aristotle has been surveyed by B. BYDÉN, 'No Prince of Perfection': Byzantine AntiAristotelianism from the Patristic Period to Pletho, in: Power and Subversion in Byzantium, eds. D. Angelov and M. Saxby. Farnham 2013, 147-176, esp. 164-165.

${ }^{151}$ Blemmydes, Epitome of Physics 7 (PG 142, 1089BC).
} 
elements and their mixtures. This view is illustrated by a drawing of concentric circles of the four elements - earth (the innermost circle), water, air, and fire (the outermost circle) - with nature lying at the centre ${ }^{152}$. In the essay, Laskaris continues his argument by invoking two phenomena of natural movement. Yet he does not do so in order to back up his initial proposition, but to attack the gross and ignorant misinterpretation of the phenomena by unnamed opponents. These opponents are alleged to have thought that when matter falls on earth and then rises through fire, and when stones are thrown and then fall down, these phenomena meant that nature in fact "turns upon itself."

Who are Laskaris' intellectual opponents called enigmatically by him "some people" ( $\tau$ เvés)? The view of nature turning upon itself is found in a text by the alchemist Zosimos of Panopolis (3rd-4th cent.), whom Laskaris never mentions in his writings. Blemmydes dabbled in alchemy and Laskaris himself was fascinated with the occult, but his fascination is not a sufficient basis to conclude that the essay represents veiled criticism of the ancient author ${ }^{153}$. Another more plausible possibility is that the essay echoes contemporary debates on the meaning of natural phenomena within the educated entourage of Laskaris. The emperor was fond of drawing philosophical conclusions from observations of nature. The treatise Explanation of the World reveals notable empiricist tendencies. In the first chapter (titled On the Elements), the author states that "the demonstration is most forceful when it abounds in observed and sensed things." 154 Thus, water poured into a container and left for a sufficiently long time evaporates and gives way to earth (namely, deposits), which shows the transformation of the elements ${ }^{155}$. In the second chapter (titled On Heaven), the author draws attention to how round stones fall to the ground faster than those with angular shapes, which explains the circular form of throwing discs and projectiles shot by catapults ${ }^{156}$. Members of Laskaris' circle would have discussed with him such natural phenomena. One can easily picture how individuals around him who were familiar with the drawing of the concentric circles of the elements in his Natural Communion could have interpreted a natural movement toward the lowest circle (earth) and the centre (nature) as a return of nature to itself. This was the misunderstanding which Laskaris wished to correct.

\section{Essay 4: Universal justice and the partiality of judges}

The fourth essay makes a critical comment on justice and judges. The context emerges from the

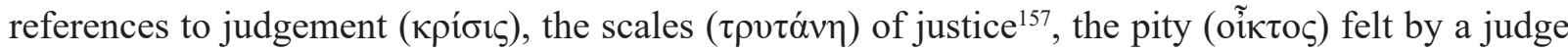
who prefers to remain silent and not "reveal secret things," and the resulting transgression of the law $(\dot{\alpha} v o ́ \mu \eta \mu \alpha)$. Theodore starts by positing the principle of universal justice. In this way "the

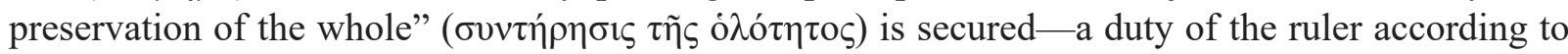

${ }^{152}$ PG 140, 1281B, 1284A, 1364B. Only rarely does the author allude in this work to the idea of God as the creator of nature,

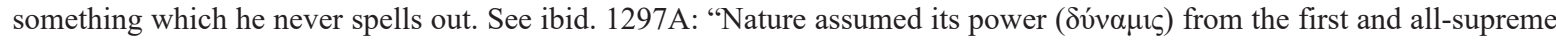

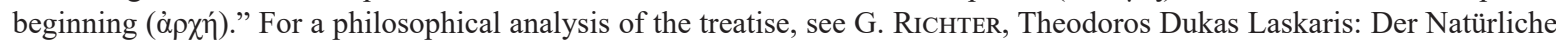
Zusammenhang. Ein Zeugnis vom Stand der byzantinischen Philosophie in der Mitte des 13. Jahrhunderts. Amsterdam 1989.

153 Zosimos, On Virtue, in M. Berthelot - C. É. Ruelle, Collection des anciens alchimistes grecs, Vol. 2. Paris 1888. 111.5-6:

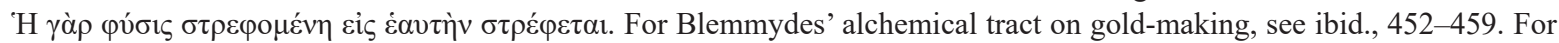
Laskaris and his complex attitude to the occult, see, for example, ep. 131 (FESTA 183-185) addressed to the metropolitan of Adrianople Germanos.

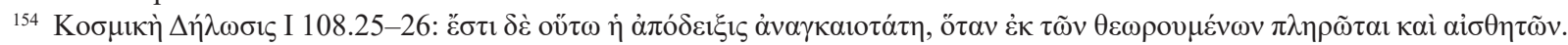

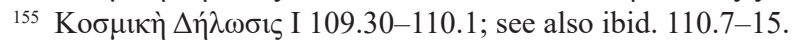

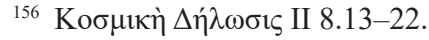

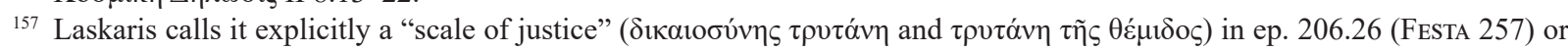

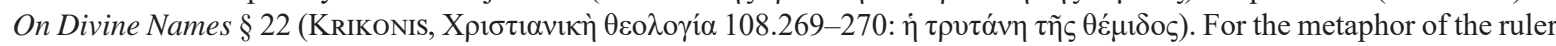
handling steadfastly the scale of justice, see his Memorial Discourse for Frederick II (TARTAGLIA, Opuscula 91.145-156); see also Blemmydes, Imperial Statue § 130 (ك̌EvČENKO-HunGER 84). 
Blemmydes ${ }^{158}$. The author makes an allusion to the corruption of a "partial" judge who "purchases" his pity and acts mercifully. The judge keeps the matter private and pursues his own self-interest. Nevertheless, secrets become public over time. The essay lacks specificity, and the author himself admits at the end that his arguments are only a hint. One wonders whether he had in mind the trial of Michael Palaiologos (autumn 1253) resulting in his acquittal. In any case, Laskaris displayed the same preoccupation with impartial and universal justice in other works. In his Memorial Discourse for Frederick II Hohenstaufen (d. 1250), he notes that the impartial administration of justice leads to the preservation of the polity while provoking implacable hatred for the ruler ${ }^{159}$. In the third chapter of the Explanation of the World he alludes to the venality of judges ${ }^{160}$. The essay shows that the fair dispensation of justice, as the author perceived it, was in the forefront of his mind during his fouryear reign.

\section{Essay 5: The satire of clergymen}

The satirical essay makes no effort to disguise its target who was a well-known individual in the empire of Nicaea in the 1240s and 1250s - the archbishop of Ephesos Nikephoros Pamphilos. Nikephoros started his career as archdeacon in the palace clergy of Vatatzes and was one of the three candidates for the patriarchal post in 1243, but was not elected on that occasion due to the emperor's objections; he would eventually become patriarch in 1260. In 1243 or 1244 he was appointed instead as the archbishop of the large and wealthy episcopal see of Ephesos ${ }^{161}$. In two satirical letters Laskaris notified Blemmydes, who was then abbot of the monastery of Saint Gregory Thaumatourgos near Ephesos, of Nikephoros' imminent assumption of pastoral responsibilities. One of the letters (Ep. 10) is a humorous comparison of the newly ordained cleric with the statue from the dream of Nebuchadnezzar in the second book of the prophet Daniel ${ }^{162}$. The other (Ep. 11) ridicules the greed of the bishop and the fiscal injustices he was about to inflict on artisans, merchants, and peasants ${ }^{163}$. Notably, the letter plays on the parable of the Pharisee and the Tax Collector (Luke 18:9-14), and foreshadows the humour of the essay: "The lowly Pharisee has welcomed the tax-collector presiding on high and has embraced with great desire the city of Ephesos as his bride." 164 The six letters of Laskaris to Nikephoros of Ephesos, all dating to a period before 1254, are marked by aloofness and confirm the tension between the two men ${ }^{165}$.

The essay composed a decade after the two epistolary satires shows that the churchman remained a subject of jokes. The essay bears resemblance to letters addressed by Laskaris to laymen, in which he lampooned members of the clergy ${ }^{166}$. The arrival of the bishop at the court on the Sunday of the

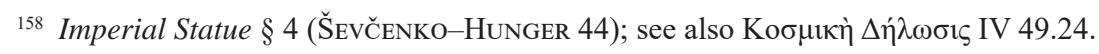

159 Tartaglia, Opuscula 91.143-92.153.

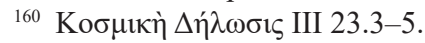

161 On the patriarchal elections in 1243 and 1259-1260, see V. LAURENT, La chronologie des patriarches de Constantinople au XIII ${ }^{\text {e }}$ s. (1208-1309). REB 27 (1969) 129-150, esp. 138-139; A. FAILER, Chronologie et composition dans l'Histoire de Georges Pachymère. REB 38 (1980) 45-53. On Nikephoros' candidacy in 1243 and the disapproval of him by Vatatzes, see Pachymeres I, 2, 15-16 (Failler I, 163.27-28,165.18-23). On the surname "Pamphilos," see J. Darrouzés, Le traité des transferts: Édition, critique et commentaire. REB 42 (1984) 147-214, esp. 153, 186.

162 Ep. 10 (FeSTA 14).

163 Ep. 11 (FESTA 15-16).

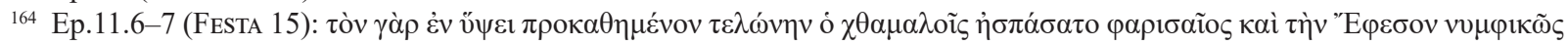

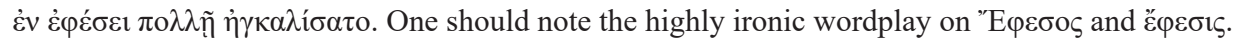

${ }^{165}$ Ep. 103 (FESTA 140-143) responds to accusations coming from the circle of the metropolitan bishop that the crown prince was not virtuous; ep. 108 (FESTA 148-149) mentions an inappropriate text written by the bishop, which offended the emperor and the patriarch.

166 See ep. 73 (FESTA 99-101) addressed to Akropolites and ep. 158 (FeSTA 218-219) addressed to Mouzalon. 
Pharisee and the Tax Collector, which opens the pre-Lenten period, was the occasion for the satirical sketch. This event is described as providential, because Nikephoros wished to display "the evils innate in him" from that Sunday rather than the following four ones, namely, the Sunday of the Prodigal Son, the Sunday of the Last Judgment, the Sunday of Forgiveness with its focus on the Fall of Adam and Eve, and the Sunday of Orthodoxy. It is unclear why Laskaris reverses the actual liturgical order of the feasts of the Sunday of the Last Judgment and the Sunday of Forgiveness. His reference

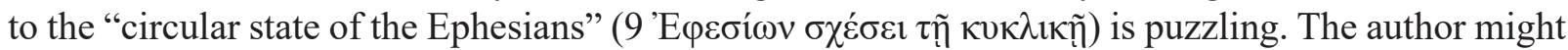
be alluding to Saint Paul's prophetic admonition to the elders of Ephesos (Acts 20.29-30) that the troubles he had with some of the inhabitants of the city would reappear in the future: "Know that after I have gone, savage wolves will come in among you, not sparing the flock. Some even from your own group will come distorting the truth in order to entice the disciples to follow them." It is also possible that Laskaris satirized a physical characteristic, the rotundness of the Ephesians. Elsewhere he used a different, but similarly "geometrical," phrase to refer to the obesity of a mocked individual

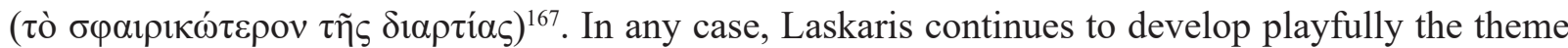
further on in the essay where he makes fun of the bishop's circular way of reasoning (14: $\pi \varepsilon \rho 1 \varphi \varepsilon \rho \tilde{\omega} \varsigma)$.

The essay approaches the Parable of the Pharisee and the Tax-Collector with an interesting twist at the end. Throughout the essay Nikephoros is cast in the role of the sanctimonious and self-righteous Pharisee. In the last sentence, the author sets himself up as the penitential and remorseful tax-collector who gained Christ's approval. He ironically asks Nikephoros ("o most wondrous man") to have consideration for him, and presents himself as "standing apart from the multitude" and being "truly the greatest." The closing of the essay plays on the tax-gathering responsibilities of the emperor and may be related to his dispute with Blemmydes in 1257 over tax-based army financing ${ }^{168}$. It also reflects Laskaris' sense of distance from the crowd that arose out of his sharp self-awareness of being a philosopher ${ }^{169}$. The theme of remorse appears, too, in his other writings - for example, in the Moral Pieces.

\section{Essay 6: The self-sacrifice of rulers}

The sixth essay comments on the gruelling experiences of rulers during military campaigns and the adverse effect this hard life has on their physical wellbeing. The essay resembles in spirit the Memorial Discourse for Frederick II, a text likewise written in the third rather than the first person, in which the crown prince had contemplated the pitiable fate of rulers who are misunderstood and maligned ${ }^{170}$. As in the Memorial Discourse, the author draws generalizations about any ruler, but the descriptions are more intimate and based on the Balkan campaign (1255-1256) that Laskaris had recently led against the Bulgarians. The sudden switch of narrative perspective at the end of the essay, where another voice is introduced and the third person "he" becomes the author of the preceding comments (that is, Laskaris), highlights the personal character of the essay. As we have seen, this ending creates the impression of an improvised composition by dictation.

The physical suffering of the ruler described in the essay resembles the complaints Laskaris made in campaign letters addressed to Mouzalon. In a letter composed in the summer of 1255 at the army camp set up in Adrianople along the Hebros River, he wrote that the freezing cold of the winter had given way to a hot summer and his soldiers were unable to quench their thirst caused by the scorching

\footnotetext{
167 Satire of the Tutor $\S 21$ (TARTAGLia, Opuscula 186.779-780).

${ }^{168}$ Ep. 44.40-53 (FESTA 57-58). This letter dates to 1257 because of the mention of the acquisition of Dyrrachion.

169 Ep. 49.78-97 (Festa 70); ep. 199.5-16 (FeSTA 244-245).

170 TARTAGLia, Opuscula 86-94.
} 
heat ${ }^{171}$. The same grievances about extreme weather conditions appear in the essay, where the private individual is said to lead a healthier life by staying home and keeping warm during the winter, when the ruler has to provide for his security. During the summer, the private individual has easy access to drinking water, while thirst torments the ruler and commander-in-chief surrounded by the dust and stench of the camp. At the end of 1255, Theodore addressed to Mouzalon another letter in which he summarized his achievements and noted the sacrifice of his body during the campaign ${ }^{172}$. The same idea appears in the essay, although the emphasis lies on explaining illness. Only the ruler who takes care of himself happens to be healthy. As Laskaris felt symptoms of bodily weakness, he looked retrospectively at the Balkan campaign and sought there the causes of his current condition. He deemed the subject worthy of broader reflections on the sorrowful destiny of rulers.

\section{BRIEF CONCLUDING REMARKS}

The six essays paint a rich self-portrait of the author. They present Laskaris in various guises: the thinker who explores the meaning of philosophical concepts (Essay 1); the austere and repentant ruler who reevaluates the pleasure of court life (Essay 2); the natural philosopher who discusses the principles of the universe (Essay 3); the social commentator who criticizes problems in his own state and society (Essay 4); the satirist with an eye for comic occasions (Essay 5); and the political theorist who reflects on rulership based on his own experiences (Essay 6). Laskaris undoubtedly valued the short pieces enough to include them in a collection prepared near the end of his life, along with letters, devotional pieces and a philosophical work. The essays are, thus, part of the editorial project by which Laskaris shaped his literary and philosophical legacy, and gave a discursive form to his self-portrait.

In contrast to other textual expressions of rulers in Byzantium until the twelfth century-for example, the orations of Leo VI, the admonitory texts "written" by Basil I and Alexios I Komnenos, or the tombstone poem of Basil II- the six essays of Theodore II Laskaris constitute a unicum in the entire Byzantine literature. Just as Laskaris' letters are, to a certain extent, the expression of the author's "person" (comparable to the letter collection of Manuel II Palaiologos about a hundred and fifty years later), the six essays capture for us, in their peculiar stylistic and structural form, the closest possible moment of an authorial self-representation of an emperor who felt torn between politics, philosophy, artistic emotionality, and an inner anguish at his demanding life. In this sense, these six short texts are among the most "modernist" pieces Medieval Greek literature has to offer.

\footnotetext{
171 Ep. 202.30-41 (FESTA 249).
}

172 Ep. 205.6-8 (FESTA 255). 

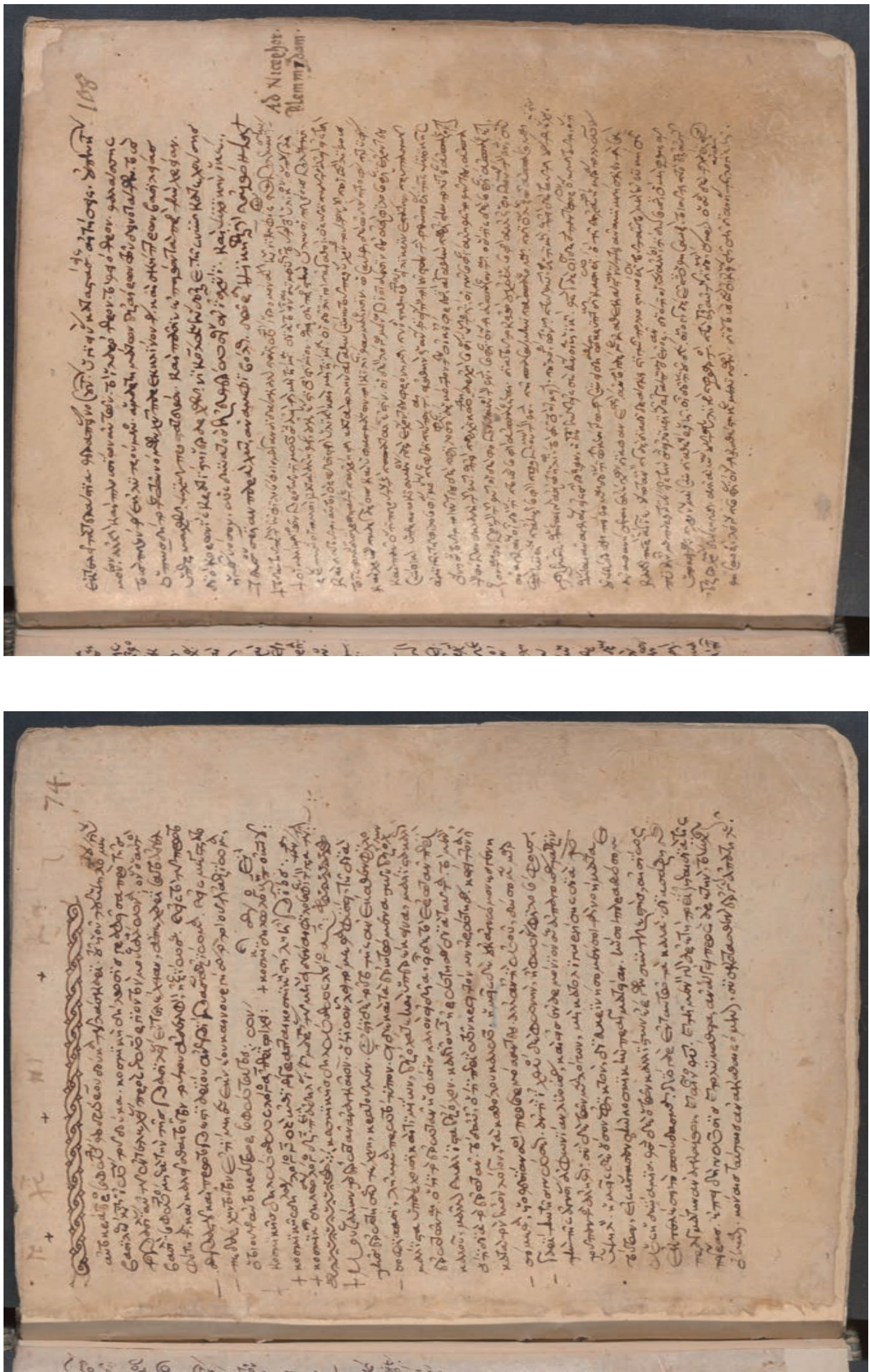

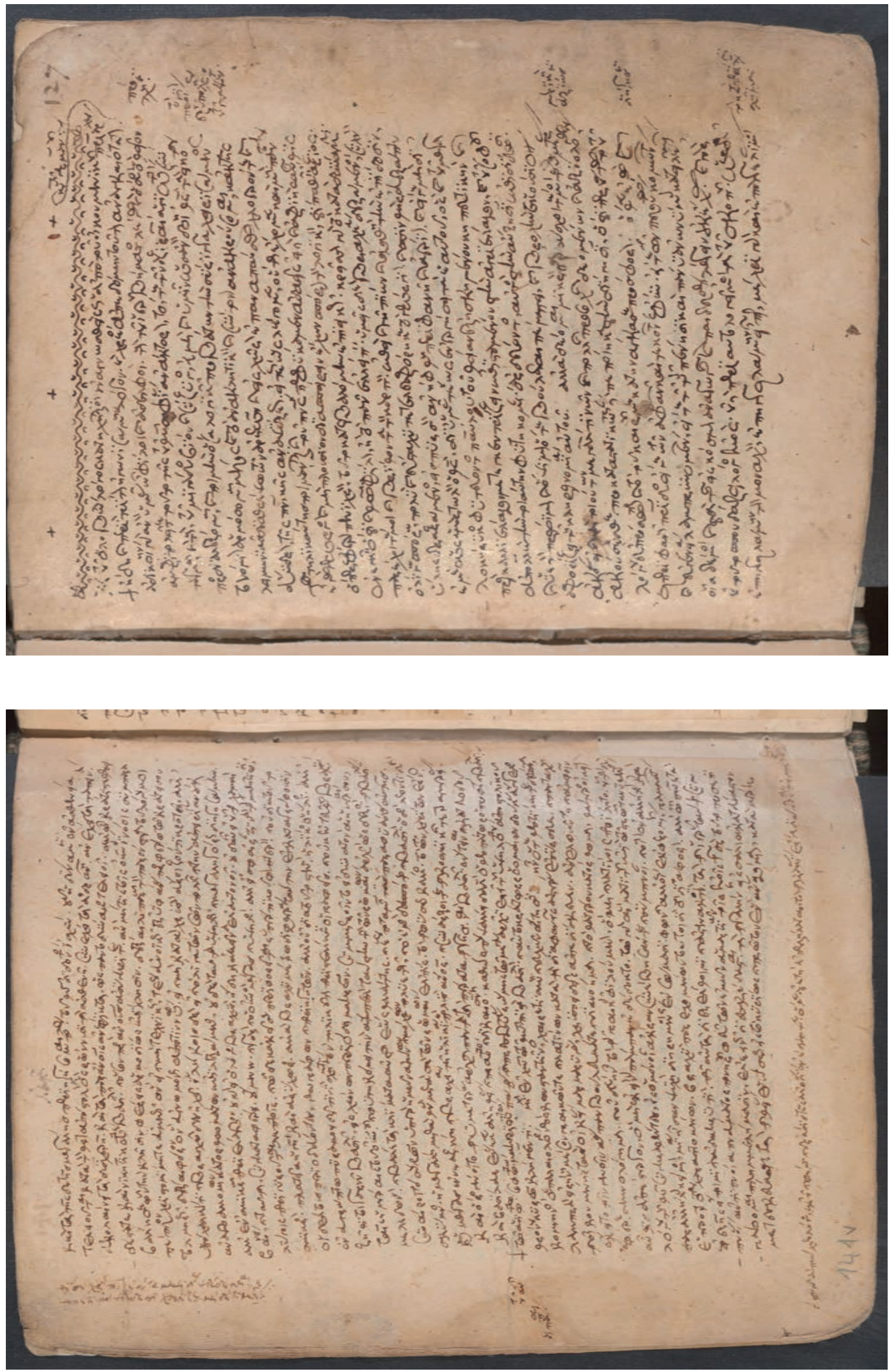
